\title{
Oosagitta gen. nov. from tropical Africa, with revision of two species and description of four new species (Coleoptera: Chrysomelidae, Galerucinae)
}

\author{
Sabine KORTENHAUS ${ }^{1} \&$ Thomas WAGNER ${ }^{2 *}$ \\ ${ }^{1,2}$ Institut für Integrierte Naturwissenschaft - Biologie, Universität Koblenz-Landau, \\ Universitätsstraße 1, D-56070 Koblenz, Germany \\ Email: thwagner@uni-koblenz.de (corresponding author) \\ ${ }^{1}$ urn:Isid:zoobank.org:author:95CDF19F-25D1-4ED7-839A-0513BACD765A \\ 2 urn:Isid:zoobank.org:author:6AF65C9C-246B-41CA-B326-2D93C427CCD1 \\ $* 42^{\text {nd }}$ contribution to the taxonomy, phylogeny and biogeography of the Galerucinae
}

\begin{abstract}
After our taxonomic revision of Ootheca Chevrolat, 1837, and the description of Oothecoides Kortenhaus \& Wagner, 2011 and Ootibia Kortenhaus \& Wagner, 2012, it became clear that a further four galerucine species, closely related to the above named taxa, form a distinct monophyletic group, that constitutes a new genus, Oosagitta gen. nov. with $O$. anningae sp. nov., O. geescheae sp. nov., $O$. melanopicta sp. nov. and $O$. thomasi sp. nov.. Exosoma angolensis Laboissière, 1939, the type species of the new genus, and Ergana minuta Laboissière, 1937 are newly transferred to Oosagitta gen. nov. All species of Oosagitta gen. nov. are characterized by a broad body and pronotum, a more or less convex dorsum and short legs, and as such are most similar to the other above named genera. The antennae of Oosagitta gen. nov. are distinctly longer than those of Ootheca, Oothecoides and Ootibia. Genital structures of the males allow a reliable identification of the genus. (Re-)descriptions are given for all species, including semi-schematic illustrations depicting the habitus outline, shape of the basal antennomeres and the median lobe. Photographs of the name-bearing types and distribution maps are provided.
\end{abstract}

Keywords. Afrotropical Region, taxonomy, Ootheca, new genus, new species.

Kortenhaus S. \& Wagner T. 2013. Oosagitta gen. nov. from tropical Africa, with revision of two species and description of four new species (Coleoptera: Chrysomelidae, Galerucinae). European Journal of Taxonomy 58: 1-24. http://dx.doi. org/10.5852/ejt.2013.58

\section{Introduction}

Over the last years we revised a number of species, originally described in the galerucine genus Ootheca Chevrolat, 1837 (Kortenhaus \& Wagner 2010) or its junior synonym Ergana Chapuis, 1879 and species later transferred from Malacosoma Chevrolat, 1837 - and its replacement name Exosoma Jacoby, 1906 - to Ootheca. We identified several species, which have to be excluded from Ootheca (Kortenhaus \& Wagner 2011, 2012). Some of them, characterized by asymmetrical structures of the median lobe and a comparatively dorsoventrally compressed body shape, have been transferred to Oothecoides Kortenhaus \& 
Wagner, 2011. Further two species, with sexual dimorphic characters of the metatibia and a distinct male genital pattern, have been transferred to and recently described in Ootibia Kortenhaus \& Wagner, 2012. Two other species, Exosoma angolensis Laboissière, 1939 and Ergana minuta Laboissière, 1937, do not belong to these taxa and have to be transferred, together with four newly described species, to a new genus that is herein described. Oosagitta gen. nov. has the broad pronotum, more or less convex dorsum, short legs and also the shape of the spermatheca in common with Ootheca, Oothecoides and Ootibia, but its antennomeres are significantly more elongated. The most distinctive character for this new group is the male genitalia, that possesses a peculiar arrow-like apical part of the endophallus, a very long median tectum and a pair of very long, elongated tectorial spures that can be considered as a synapomorphic character.

\section{Material and methods}

\section{Abbreviations}

Our revision is based on 1433 specimens from the following collections (Tab. 1):

$\mathrm{BMNH}=$ The Natural History Museum, London

HNHM $=$ Hungarian Natural History Museum, Budapest

IRSNB = Institut Royal des Sciences Naturelles de Belgique, Bruxelles

MCGD = Museo Storia di Naturale "Diacomo Doria", Genova

MNHN = Muséum national d'Histoire naturelle, Paris

MNHU $=$ Museum für Naturkunde der Humboldt Universität, Berlin

MRAC $=$ Musée Royal d'Afrique Centrale, Tervuren

NMK = National Museums of Kenya, Nairobi

ZFMK $=$ Zoologisches Forschungsmusuem Alexander Koenig, Bonn

$\mathrm{ZMUH}=$ Zoologisches Museum der Universität Hamburg

Table 1. Numbers of examined specimens in the studied collections.

\begin{tabular}{|c|c|c|c|c|c|c|c|}
\hline & 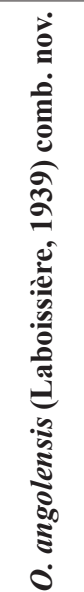 & 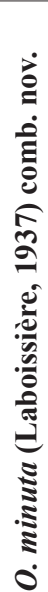 & 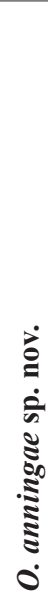 & 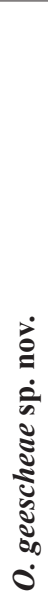 & 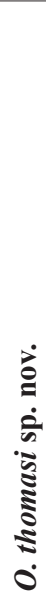 & 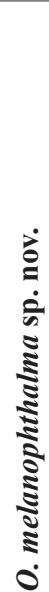 & $\stackrel{\bar{\sigma}}{\underline{\theta}}$ \\
\hline BMNH & 1 & 1 & & 1 & & & 3 \\
\hline HNHM & & & & 1 & & & 1 \\
\hline IRSN & 41 & 7 & & 5 & & & 53 \\
\hline MCGD & & 1 & & & & & 1 \\
\hline MNHN & & & 2 & 1 & & & 3 \\
\hline MNHU & 5 & 1 & 1 & 2 & & & 9 \\
\hline MRAC & 1321 & 2 & 8 & 4 & 6 & 5 & 1346 \\
\hline NMK & & & & 1 & & & 1 \\
\hline ZFMK & 15 & & & & & & 15 \\
\hline ZMUH & & 1 & & & & & 1 \\
\hline total & 1383 & 13 & 11 & 15 & 6 & 5 & 1433 \\
\hline
\end{tabular}


Depending on the available specimens, 11 to 30 specimens were measured per species. Absolute measurements include:

$\mathrm{TL}=$ total body length from apex of labrum to apex of elytron

$\mathrm{PL}=$ maximum height in lateral view; pronotal length

$\mathrm{PW}=$ maximum pronotal width

$\mathrm{EL}=$ length of elytron

$\mathrm{EW}=$ maximum width of both elytra combined

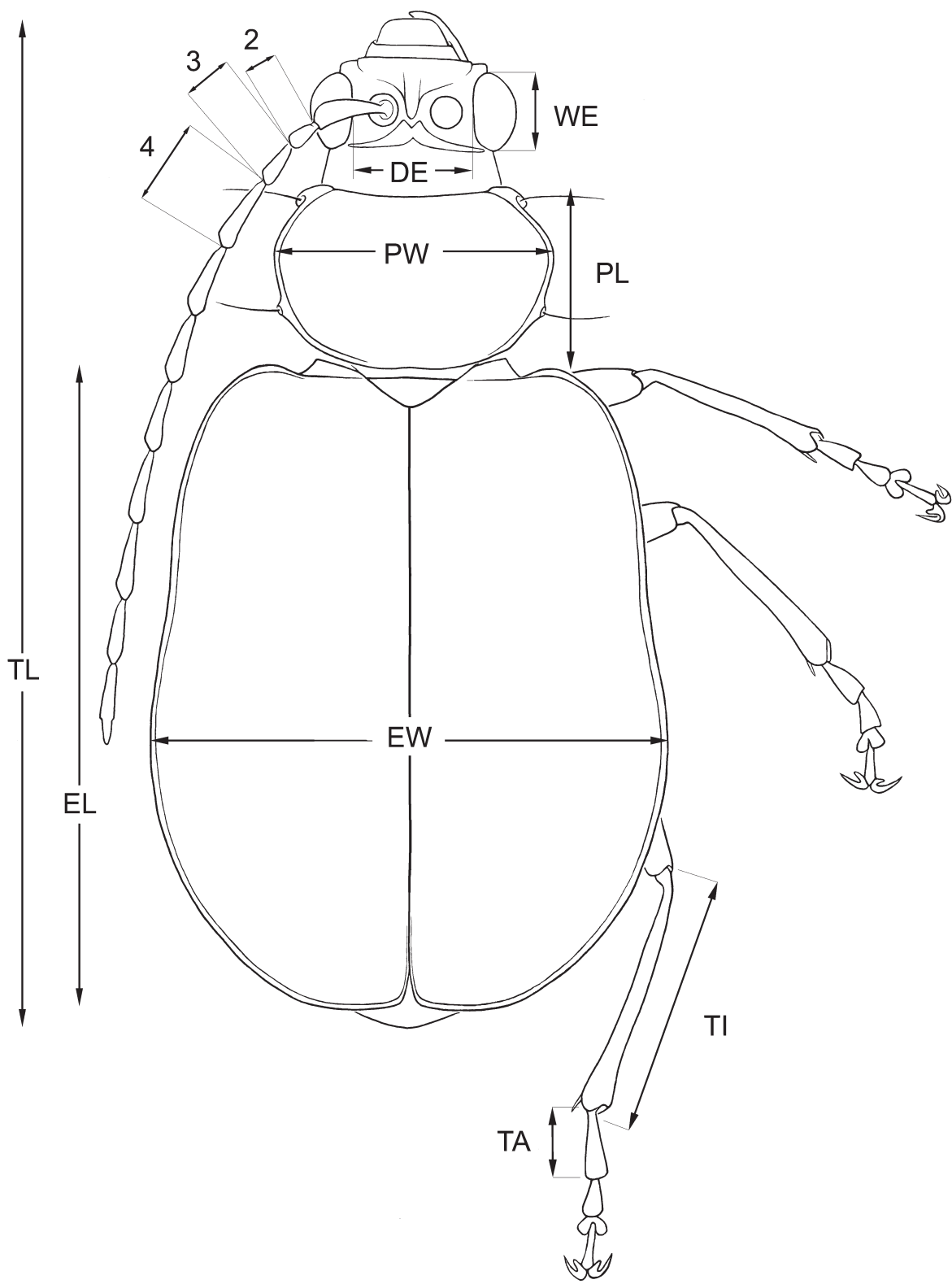

Fig. 1. Measurements taken. Absolute measurements: $T L=$ total length from apex of labrum to apex of elytron; $\mathrm{PL}=$ pronotal length; $\mathrm{PW}=$ maximum pronotal width; $\mathrm{EL}=$ elytral length; $\mathrm{EW}=$ maximum width of elytra combined. Relative measurements: 2, 3, 4 = length of second, third and fourth antennomeres; $\mathrm{DE}=$ minimum distance between eyes; $\mathrm{WE}=$ maximum width of eye; $\mathrm{TA}=$ length of basimetatarsus; $\mathrm{TI}=$ length of metatibia. 
Relative measurements were:

$\mathrm{PW} / \mathrm{PL}=$ pronotal width to pronotal length

$\mathrm{EW} / \mathrm{EL}=$ maximum width of both elytra combined to elytral length

$2 . / 3 . \quad=$ length of second to third antennomere

3./4. $\quad=$ length of third to fourth antennomere

$\mathrm{WE} / \mathrm{DE}=$ maximum width of eye to minimum distance between eyes

$\mathrm{TA} / \mathrm{TI}=$ length of basimetatarsus to length of metatibia (Fig. 1)

For each species, a standard set of figures is given. External characters are documented by dorsal semi-schematic habitus illustrations, including the left antenna, detailed illustrations of the four basal antennomeres of males and females, and legs on the right-hand side of the body. In one case, the illustration depicts the elytral colour pattern. The male genitalic structures are illustrated in dorsal and lateral views. Variation in spermatecal shape is very small between species and therefore only given in the description of the genus. General structures of the head, ventral side of the thorax and metathoracic wing are very similar to those of Ootheca, and details can be found in our revision of that genus (Kortenhaus \& Wagner 2010). For name-bearing type specimens, the label data are cited verbatim and sexes are given; data for all other specimens have been standardized and include the following information: country, province, numbers of specimens, locality, latitude and longitude coordinates, altitude, date, collector and depositary (in brackets). Localities are given as precisely as possible. Countries and localities (e.g. towns), recorded as traditional names on labels, are listed, together with their current names; coordinates were taken from the geographical database GeoNames; if a location remains unidentified, mean coordinates of the given district or region were used; in cases of doubt, where there was one location with many coordinate possibilities, we did not allocate coordinates. Data were imported into the program ArcGis (ESRI-ArcMap Version 9.3) to produce GIS-based distribution maps.

\section{Results}

Class Hexapoda Blainville, 1816

Order Coleoptera Linnaeus, 1758

Superfamily Chrysomeloidea Latreille, 1802

Family Chrysomelidae Latreille, 1802

Subfamily Galerucinae Latreille, 1802

Oosagitta gen. nov.

urn:1sid:zoobank.org:act:11FBE0A7-E2BB-4072-B6BD-87B5AEBBA47E

\section{Type species}

Exosoma angolensis Laboissière, 1939.

\section{Differential diagnosis}

Oosagitta gen. nov. are Galerucinae with an elongate-ovate body shape, elytron slightly widened in the posterior half, convexly rounded, and a pronotum slightly narrower than the elytra (Figs 2, 10, 15, 19, 23, 27). Head broad, with widely separated, strongly protruding eyes (Fig. 1). Legs short and robust, the basi-tarsomeres are slightly enlarged and the claws appendiculate (Fig. 4).

From Ootibia it can be differentiated by the characteristic shaped metatibia of the male specimens. From this genus, as from Ootheca and Oothecoides, it can be differentiated by the long and slender antennomeres. The mean antennal length to total body length ratio of Oosagitta gen. nov. is $0.60-0.93$, with an overlap ratio to the other three genera of 0.60 in O. minuta comb. nov. Thus Oosagitta gen. nov. can be differentiated from Ootheca (mean antennal length to total body length ratio $0.47-0.61$ ), 
from most specimens of Oothecoides (0.61-0.72) and from Ootibia (0.66-0.71). Length of the second antennomere is about $60 \%$ of the third and length of the third antennomere about $70 \%$ of the fourth (Figs 5, 11, 16, 20, 24, 28). With respect to the maximum height in lateral view, Oosagitta gen. nov. (Fig. 3) is similarly dorso-ventrally compressed as Oothecoides, while Ootheca and Ootibia are more bulged. Due to significant overlap in body size, measurements and colouration at least of some species, a reliable identification of these four genera is doubtless possible by dissection of the male genitalia.

The symmetric median lobe of Oosagitta gen. nov. is poorly conical towards apex, slightly down-curved in lateral view, tapering to two more or less elongated tectorial spures separated by an incision and has dilated basal orifice. The tectum possesses a broad base and a narrow apex. The endophallus shows two triangular appendices at its apex (Figs 7A, 12A, 17A, 21 A, 25A, 29A), the endophallus brush emerges from this arrow-like structure (Figs 7B, 12B, 17B, 21A, 25B, 29A). This endophallus-"armature" of Oosagitta gen. nov. allows a clear differentiation from the shape of the endophallus of Ootheca. The similarity between aedeagal structures of Oosagitta gen. nov. and those of Ootheca is obvious: the symmetrical median lobe of Ootheca is usually parallel-sided, slightly conical towards the apex, or constricted in the middle. The apex can be either rounded or pointed without an apical incision, or have a deeply U-shaped apical incision. In lateral view, the median lobe is more or less evenly downcurved. The tectum is very characteristic in Ootheca, consisting of two dorsal, more or less slender, often apically hooked, tectorial spurs that are attached at the base of the apical third of the median lobe, and extend from its middle sometimes to near its apex. However no long median tectum occurs in Ootheca. The apical part of the symmetrical endophallus can usually be distinguished clearly between the bases of the tectorial spurs.

The main difference between Oosagitta gen. nov. and Oothecoides concerns the endophallus: only Oosagitta gen. nov. possesses a symmetrical triangular, arrow-like apex of the endophallus, Oothecoides has two very specific asymmetrical spines. The aedeagal shape of Oosagitta gen. nov. differs strongly from that of Ootibia. The shape of the median lobe in Ootibia (obtuse, compact, almost rectangular, parallel-sided, slightly conical towards apex, slightly down-curved in lateral view, with a very dilated basal orifice) is also different. Apically, the median lobe of Ootibia displays two ventrally situated projections, like "ears" (in dorsal view), which taper to form one or two points (in lateral view). The endophallus has a peculiar endophallic brush and two symmetrical triangular appendices.

\section{Etymology}

Combination of Ootheca and sagitta, which refers to the arrow-like shape of the endophallus; gender: female.

\section{Description}

Total Length. 3.10-6.20 mm; means of total body length for the species range from 3.75 to $5.54 \mathrm{~mm}$. Females are somewhat longer than males.

HEAD. Yellowish to dark brown, labrum in the same colour as head, only in O. geescheae sp. nov., the yellowish head becomes darker towards labrum. Rarely (O. melanopicta sp. nov.) with dark brown to black patch behind the eye. Maxillary palps yellowish to brown, last palpomere conical with fine apex. Eyes convex and ovate, separated by triangular frontal calli, and a transverse, curved depression divides the frons from the vertex (Fig. 1); ratio for maximum eye width to minimum distance between eyes varies from $0.55-0.92$ (means of species vary between 0.67 and 0.83 ). Antennae completely yellowish (O. anningae sp. nov., $O$. melanopicta sp. nov.), brown (O. angolensis comb. nov.), yellowish and the apical antennomere with darker apex (O. geescheae sp. nov.), basal first antennal article yellowish, antennomeres $2-11$ brown ( $O$. thomasi sp. nov.) or basal four antennomeres yellowish, antennae becoming darker towards apex (O. minuta comb. nov.). Mean antennal length ratio to total body 
length ratio $0.60-0.93$; mean length ratio of antennomere two to three $0.43-0.64$; mean length ratio of antennomere three to four $0.69-0.83$.

THORAX. Pronotum convexly rounded dorsally, lateral margins clearly differentiated from disc, anterior angles rounded (Fig. 1), disc convexly rounded; finely punctate, unicolourous yellowish or brown; pronotal length $0.65-1.30 \mathrm{~mm}$ (means of species vary between 0.81 and $1.17 \mathrm{~mm}$ ); pronotal width $1.00-2.00 \mathrm{~mm}$ (means of species vary between 1.28 and $1.85 \mathrm{~mm}$ ); pronotal width to length ratio 1.41$1.94 \mathrm{~mm}$ (means of species vary between 1.56 and $1.76 \mathrm{~mm}$ ). Prothorax dark brown to yellowish. Elytron unicolourous or with a brown base and apex of elytron in only one species (O. geescheae sp. nov.); elytron coarsely and more deeply punctate than pronotum; punctation irregular; length of elytron 2.35-4.95 $\mathrm{mm}$ (means of species vary between 2.82 and $4.33 \mathrm{~mm}$ ); maximum width of elytra combined $1.80-3.70 \mathrm{~mm}$ (means of species vary between 2.23 and $3.31 \mathrm{~mm}$ ); maximum width of elytra combined to length of elytron ratio $0.66-0.88$ (means of species vary between 0.72 and 0.88 ). Scutellum almost triangular, dark brown/black or yellowish. Meso- and metathorax in same colour. Legs unicolourous yellowish to brown or dark brown with paler brown coxae and distal/proximal parts of femur and tibia (O. minuta comb. nov.). Mean length of metatarsus to length of metatibia 0.24-0.35 (means of species vary between 0.29 and 0.32 ).

Abdominal Ventrites. Five visible ventrites (seven sternites; Fig. 3) of the same colour as the pro-/ meso- and metathorax. Apical sternite in females evenly rounded, males with two incisions in outer apical margin.

Male genitalia. Median lobe, tectum and endophallus symmetrical (Figs 7, 12, 17, 21, 25, 29). Median lobe slightly waisted in the middle and conical towards apex, where it is pointed (Figs 12A, 29A) or shallowly incised (Figs 7A, 17A, 21A, 25A). In lateral view, median lobe is more or less curved ventrally (Figs 7C, 12C, 21C, 25B, 29B), sometimes with significant hook (Fig. 17C). The tectum with broad base and strongly narrowed to apex, long as the ventral part of the median lobe (Figs 7A, 17A, 21A, 25A, 29A) or shorter (Fig. 12A), covering most parts of the endophallus by forming a tapering tip (Figs 7, 25 29), a slender, rectangular structure (Fig. 21) or a shorter, conical apex (Figs 12, 17). The median part of the tectum has moveable, slender tectorial spures on each side that are straight at apex (Figs 7, 21, 25, 29), hooked (Fig. 12) or crossed (Fig. 17, 29). The endophallus possesses two triangular appendices at its apex, giving it an arrow-like appearance (Figs 7B, 12B, 17B, 21A, 25A, 29A). The basal aedeagal orifice is very dilated with an incision (Figs 7A, 12A, 17A, 21A, 25A, 29A).

Female Genitalia. Spermatheca with spherical nodulus. Spermathecal ductus slightly sunken in the nodulus, cornu slender, strongly and evenly curved (Fig. 6).

\section{Host plants, biology and immature stages}

Unknown.

Oosagitta angolensis (Laboissière, 1939) comb. nov.

Figs 2-9

Exosoma angolensis Laboissière, 1939: 112-113.

\section{Differential diagnosis}

Oosagitta angolensis comb. nov. has a brown head and pronotum and yellowish elytron, brown legs and underside, while $O$. geescheae sp. nov. has a brown pattern on yellowish elytron, legs and underside yellowish, $O$. thomasi sp. nov. is yellowish with brown antennae - except the basal antennal article, $O$. melanoptica sp. nov. and O. anningae sp. nov. are completely yellowish and O. minuta comb. nov. 
has a dark brown elytron, legs and underside and is much smaller. Oosagitta angolensis comb. nov. is on average the largest species of the group, and, in the majority of cases, can be easily differentiated from other species by size. Total body length varies between 4.90 and $6.20 \mathrm{~mm}(O$. geescheae sp. nov. 4.50-4.80 mm, O. anningae sp. nov. $4.25-5.35 \mathrm{~mm}$, O. minuta comb. nov. $3.10-4.20 \mathrm{~mm}$, O. thomasi sp. nov. 4.65-5.50 mm, $O$. melanoptica sp. nov. 4.15-4.70 mm). The shape of the median lobe with slender, incised apex, long tectum with very slender tectorial spures allows a clear identification of the males.

\section{Type material}

\section{Holotype}

§ิ, "Kuvangu mars 1933/Angola Miss. Sc. Suisse, 1932-33/Coll. R. I Sc. N. B./Exosoma angolensis m., V. Laboissière - Det. 1939/Holotype/AfriGa specimen 753, documented 25.VII.2005" (IRSNB). (Fig. 9).

\section{Type locality}

ANGOLA: -14.4/16.4.
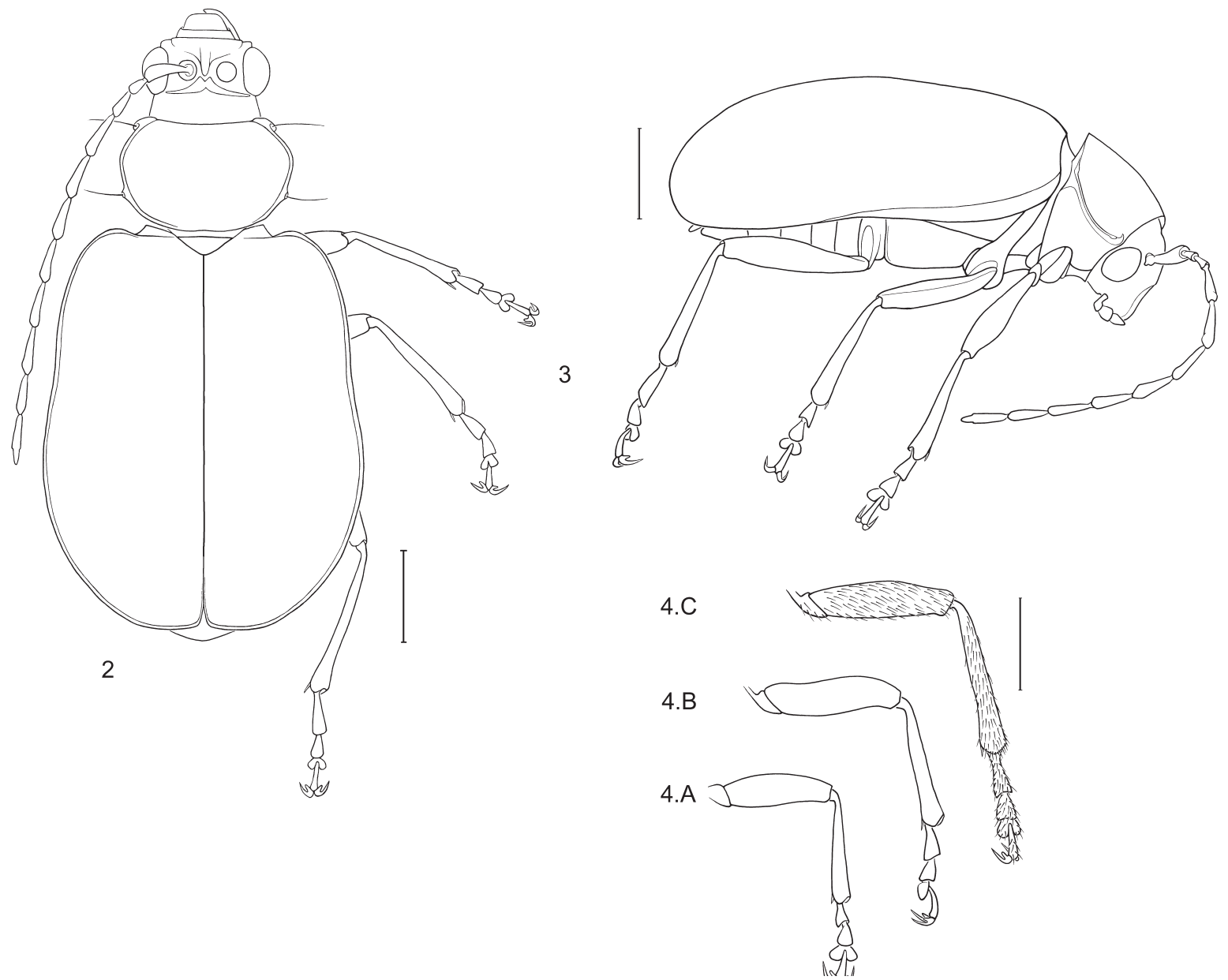

Figs 2-4. Oosagitta angolensis comb. nov. 2. Habitus, semi-schematic dorsal view, view, . . 4. Legs: A. Prothoracic leg. B. Mesothoracic leg. C. Metathoracic leg. Scale bars $=1 \mathrm{~mm}$. 


\section{Other material examined}

DEMOCRATIC REPUBLIC OF THE CONGO: 2 exx., Kasenga, -10.36/28.63, Feb. 1912, Dr. Bequaert (MRAC); 68 exx., Lulua, Kapanga, -8.35/22.58, Dec. 1931, G.F. Overlaet (MRAC); 6 exx., Lulua, Sandoa, -9.68/22.86, Jan.-Dec. 1931, G.F. Overlaet (MRAC); 5 exx., Lulua, Tshibamba, -8.25/24.37, Dec. 1931, G.F. Overlaet (MRAC); 41 exx., Lulua, Sandoa, Jan.-Dec. 1932, G.F. Overlaet (MRAC); 274 exx., Lulua, Tshibamba, Jan./Feb. 1932, G.F. Overlaet (MRAC); 1 ex., Kafakumba, -9.68/23.73, Dec. 1932, G.F. Overlaet (MRAC); 625 exx., Lulua, Kapanga, Sep.-Dec. 1932, G.F. Overlaet (MRAC); 316 exx., Lulua, Kapanga, May-Dec. 1933, G.F. Overlaet (MRAC); 11 exx., Mukonkoto, -10.30/23.95, Jan. 1937 (IRSNB); 7 exx., Lulua: Kabomba, -6.20/22.37, Nov. 1937, Vanderstichele (MRAC); 1 ex., Lulua: Kabomba, Dec. 1937, Garlier (MRAC); 1 ex., Ngowa-Kwango, Dec. 1938, P. J. Mertens (IRSNB); 1 ex., Maka-Lualaba, 3.13/26.78, Jan. 1939, H.J. Bredo (IRSNB); 2 exx., Musosa, -8.38/29.63, Sep. 1939, H.J. Bredo (IRSNB); 4 exx., Mabwe, r.E. lac Upemba, 585 m, -8.65/26.52, Dec. 1948, Miss. G.F.
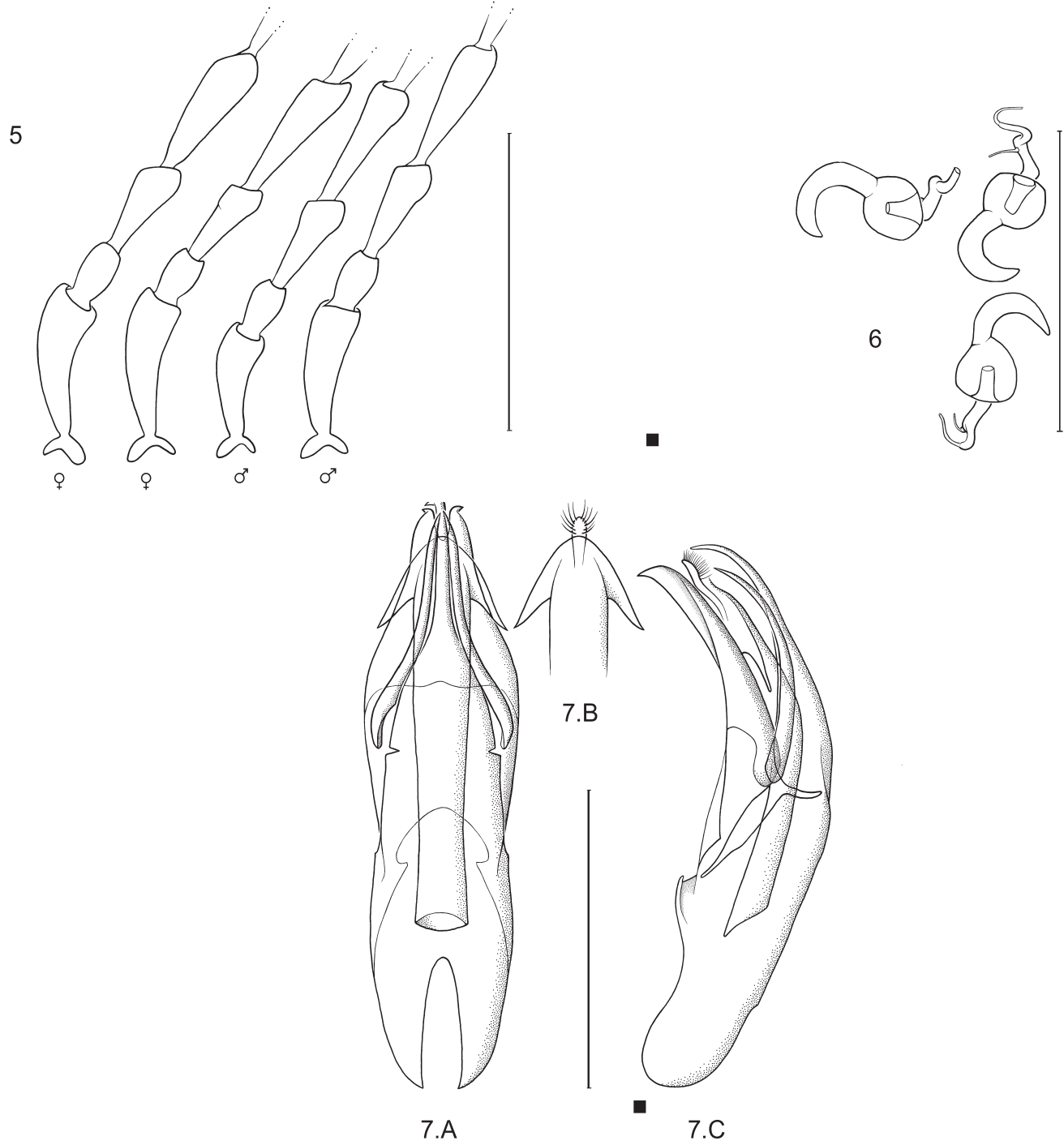

Figs 5-7. Oosagitta angolensis comb. nov. 5. Basal four antennomeres of $2 \widehat{\partial} \partial$ and $2 q q$. 6. Spermathecae of 3 우. 7. Median lobe: A. Dorsal. B. Detail: apex of endophallus. C. Lateral. Scale bars $=1 \mathrm{~mm}$. 


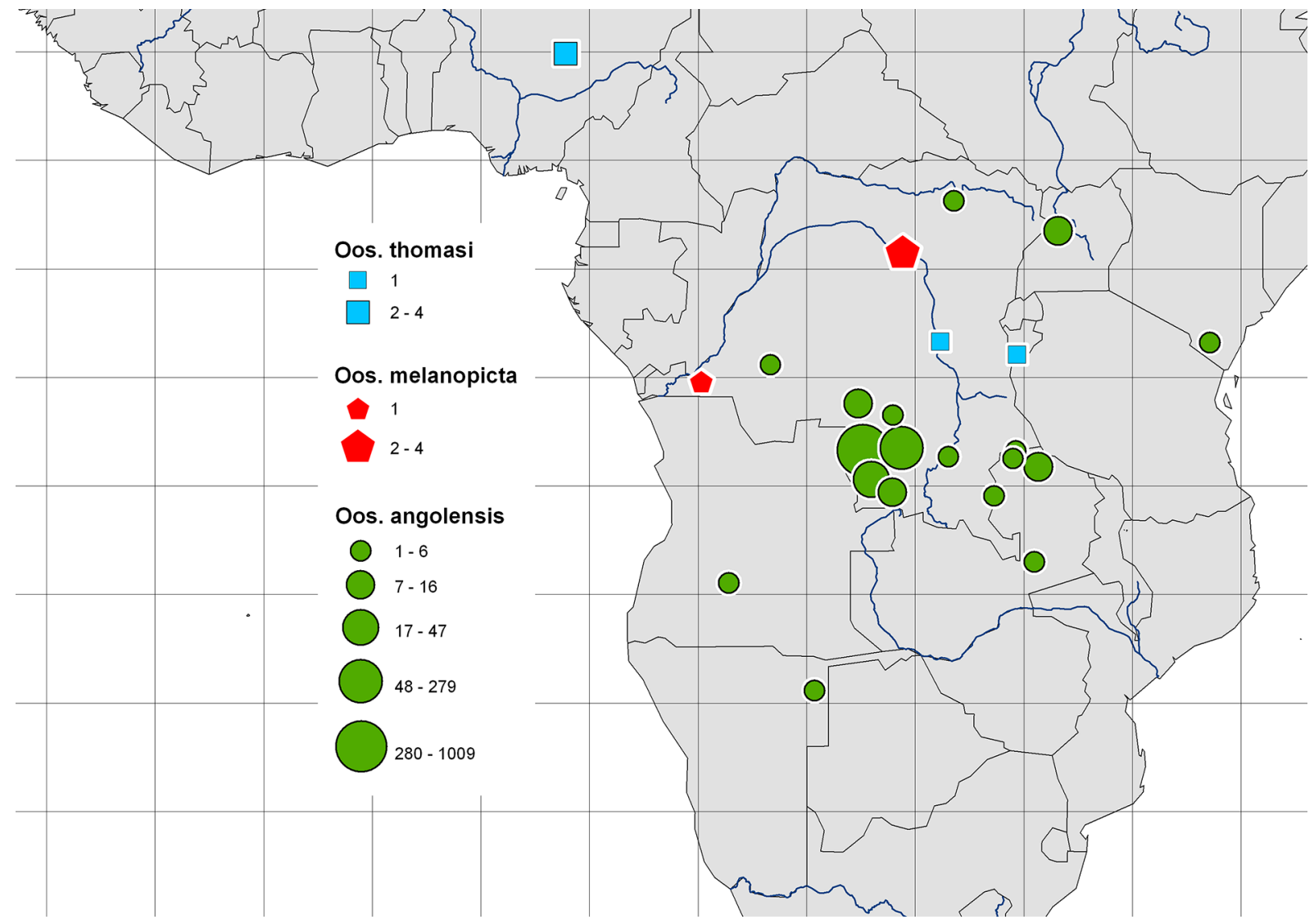

Fig. 8. Distribution of $O$. angolensis comb. nov., $O$. melanopicta sp. nov. and $O$. thomasi sp. nov.

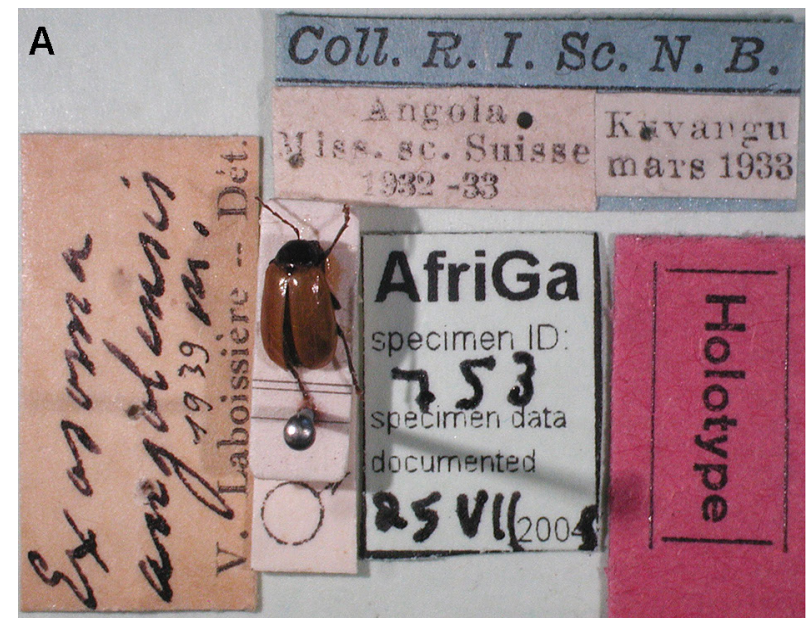

B

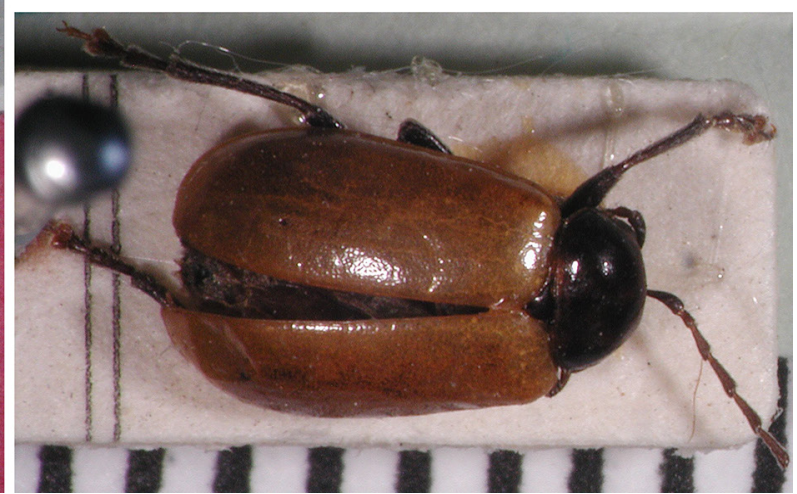

Fig. 9. Holotype of Oosagitta angolensis comb. nov. A. Overview with labels. B. Close-up of specimen. 
de Witte (IRSNB); 1 ex. Sankuru, Gandajika, -6.75/23.95, Oct. 1950, de Francquen (MRAC); 1 ex., Bas-Congo, Kimwanza, -4.427/18.33, May 1956, Van Eyen (MRAC).

KENYA: 1 ex., Voi, 2000 ft, -3.39/38.56, Nov. 1948, J.G. Williams (BMNH).

NAMIBIA: 1 ex., Bushmanland: Klein Dobe, -19.42/20.35, Feb. 1992, Namibia Expedition ZMB, M. Uhlig (MNHU).

UGANDA: 15 exx., District Masindi, Budono Forest n. Sonso, 1.75/31.58, Jul. 1995, Th. Wagner (ZFMK).

ZAMBIA: 16 exx., Kabwé, -9.12/30.67, Feb. 1944, H.J. Bredo (IRSNB), 6 exx., Mweru-Wantipa, -8.75/29.50, Mar. 1944, H.J. Bredo (IRSNB); 4 exx., 29 km NW Chipata, Kamanga, 825 m, -13.50/30.48, Mar. 1993, M. Uhlig (MNHU).

\section{Redescription}

MeAsurements. $\mathrm{n}=30$, total length 4.90-6.20 mm (mean $5.54 \mathrm{~mm}$; Fig. 2); maximum height in lateral view $1.75-2.35 \mathrm{~mm}$ (mean $2.00 \mathrm{~mm}$ ); (Fig. 3).

HEAD. Brown. Maximum width of eye to minimum distance between eyes 0.57-0.77 (mean 0.67). Length of second to third antennomere $0.46-0.75$ (mean 0.58 ), length third to fourth antennomere $0.59-0.81$ (mean 0.69; Fig. 5). Antennae brown. Mean antennal length to total body length ratio 0.82 .

Thorax. Brown as head. Pronotum brown with delicate punctation on the flat disc. Pronotal width $1.60-2.00 \mathrm{~mm}$ (mean $1.85 \mathrm{~mm}$ ), length of pronotum $1.00-1.30 \mathrm{~mm}$ (mean $1.17 \mathrm{~mm}$ ), pronotal width to length 1.43-1.67 (mean 1.59). Elytron yellow to yellowish-brown with irregular, coarse punctation. Elytral length $3.70-4.75 \mathrm{~mm}$ (mean $4.28 \mathrm{~mm}$ ), maximum width of both elytra combined $2.80-3.70 \mathrm{~mm}$ (mean $3.31 \mathrm{~mm}$ ), ratio of maximum width of elytra combined to length of elytron $0.71-0.87$ (mean 0.77). Scutellum brown, delicate punctation like pronotum. Underside and legs entirely brown. Length of basimetatarsus to length of metatibia $0.27-0.31$ (mean 0.30 ).

ABDomen. Brown.

Male genitalia. Median lobe slightly waisted in dorsal view (Fig. 7A), conical and incised at apex. Tectum is conical with a very elongated, slender apical part that is bent ventrally at the apex. It has long, slender tectorial spures at each side (Fig. 7A, C). Endophallus brush emerges from broad, arrow-like structure (Fig. 7B). Orifice of median lobe is ovoid with a rather deep incision (Fig. 7A).

\section{Distribution}

Widely distributed in Central, East and Southern Africa, from the Congo Basin towards Kenya in the northeast and to Zambia and northern Namibia in the South (Fig. 8).

Oosagitta minuta (Laboissière. 1937) comb. nov.

Figs 10-14

Ergana minuta Laboissière, 1937: 151-152.

\section{Differential diagnosis}

Oosagitta minuta comb. nov. is the smallest species of the genus with a total body length between 3.10 and $4.20 \mathrm{~mm}$. There is no other specimen of the other five species of such small size known. Antennae of O. minuta comb. nov. are shorter than those of the other described species: mean antennal length to total body length is $0.56-0.65$ (other species $0.75-1.00$ ). Also the coloration differs strongly from the other species, since $O$. minuta comb. nov. has dark brown elytron, while all other species show yellowish to yellowish-brown elytron throughout or yellow with brownish base and apex (O. geescheae sp. nov.). 


\section{Type material}

\section{Lectotype}

đ, "Uganda, Busso Busoga, May 1909, Dr. E. Bayon/Mus. Civ. Genova/Type male/Ergana minuta, m, V. Laboissière m. V. Laboissière - Det./AfriGa specimen ID 885, 17.IV.2004" (MCGD). A lectotype is herein designated to fix the name on a single specimen. (Fig. 14).

Paralectotype

1 ठ, same data as lectotype, additionally "Le Moult vend. via Reinbek, Eing. Nr. 1, 1957” (ZMUH).

\section{Type locality}

UGANDA: Bussoga, $-0.23 / 30.11$.
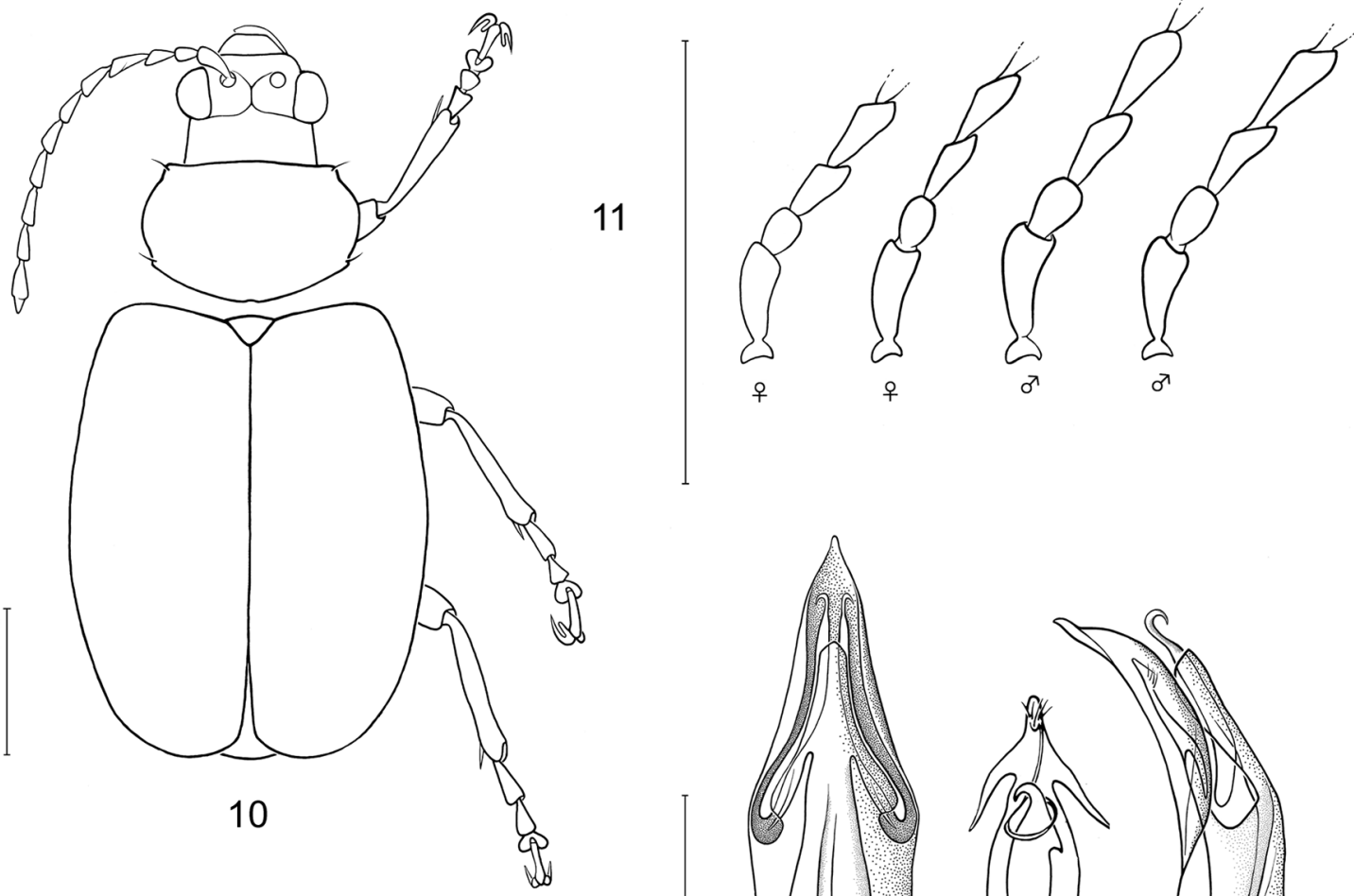

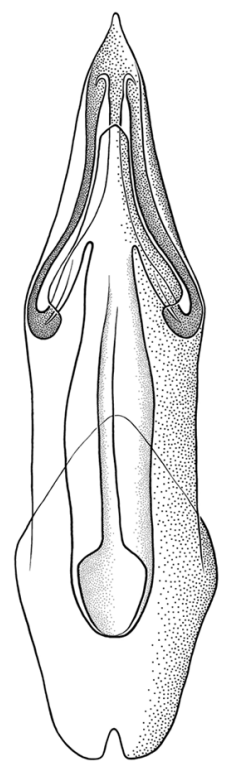

12.A

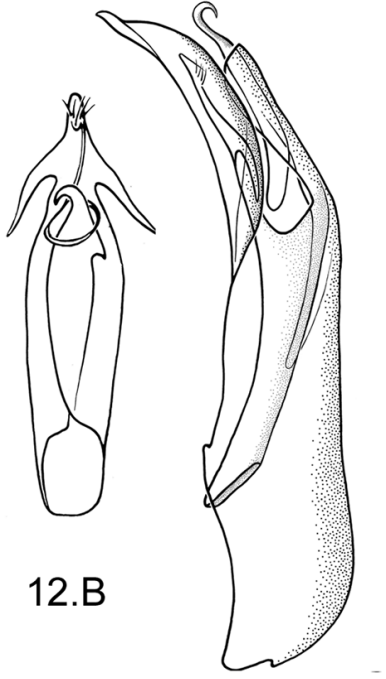

12.C

Figs 10-12. Oosagitta minuta comb. nov. 10. Habitus, semi-schematic dorsal view. 11. Basal four

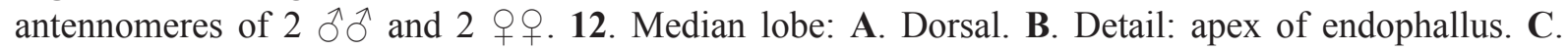
Lateral. Scale bars $=1 \mathrm{~mm}$. 


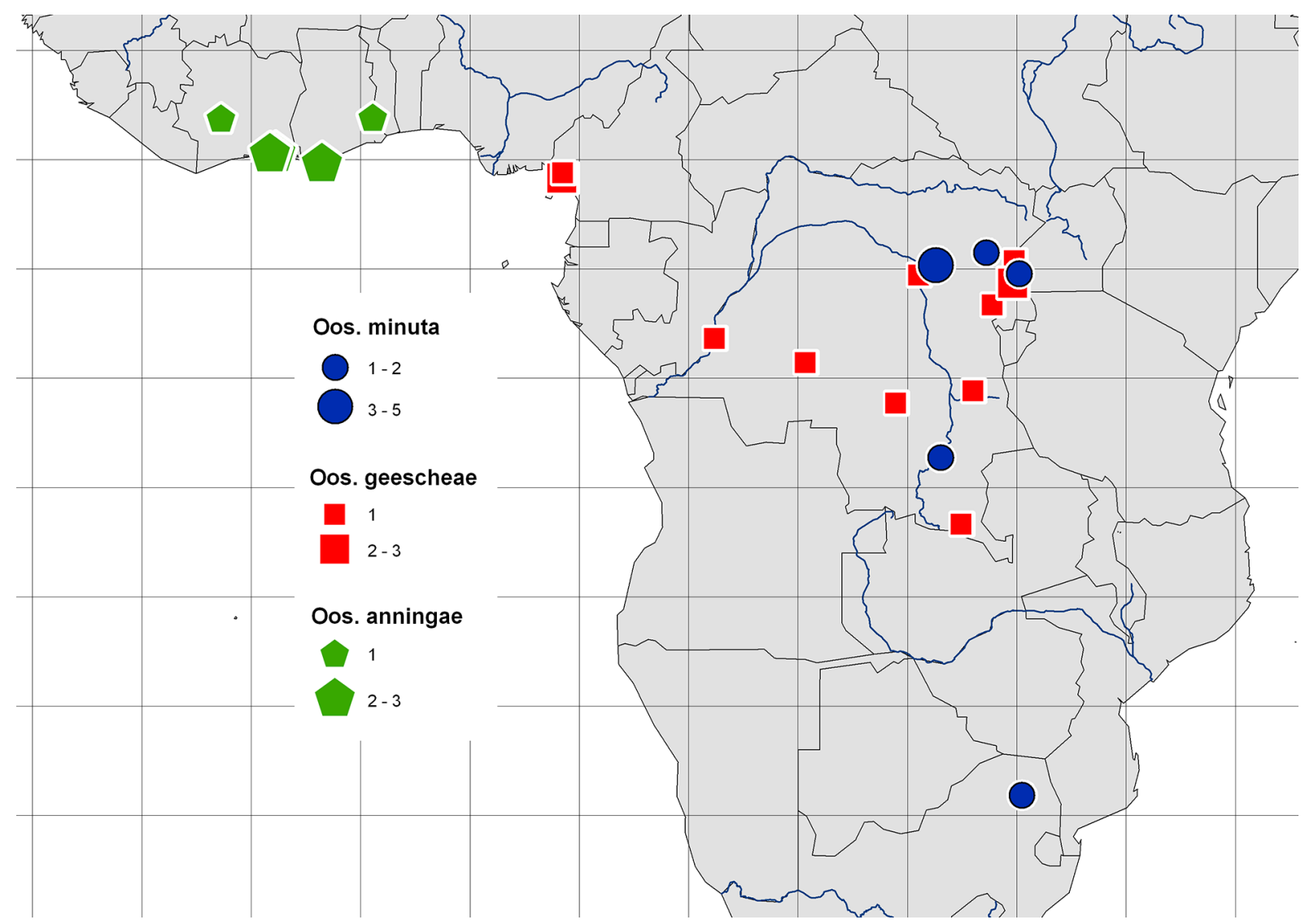

Fig. 13. Distribution of $O$. minuta comb. nov., $O$. anningae sp. nov. and $O$. geescheae sp. nov.
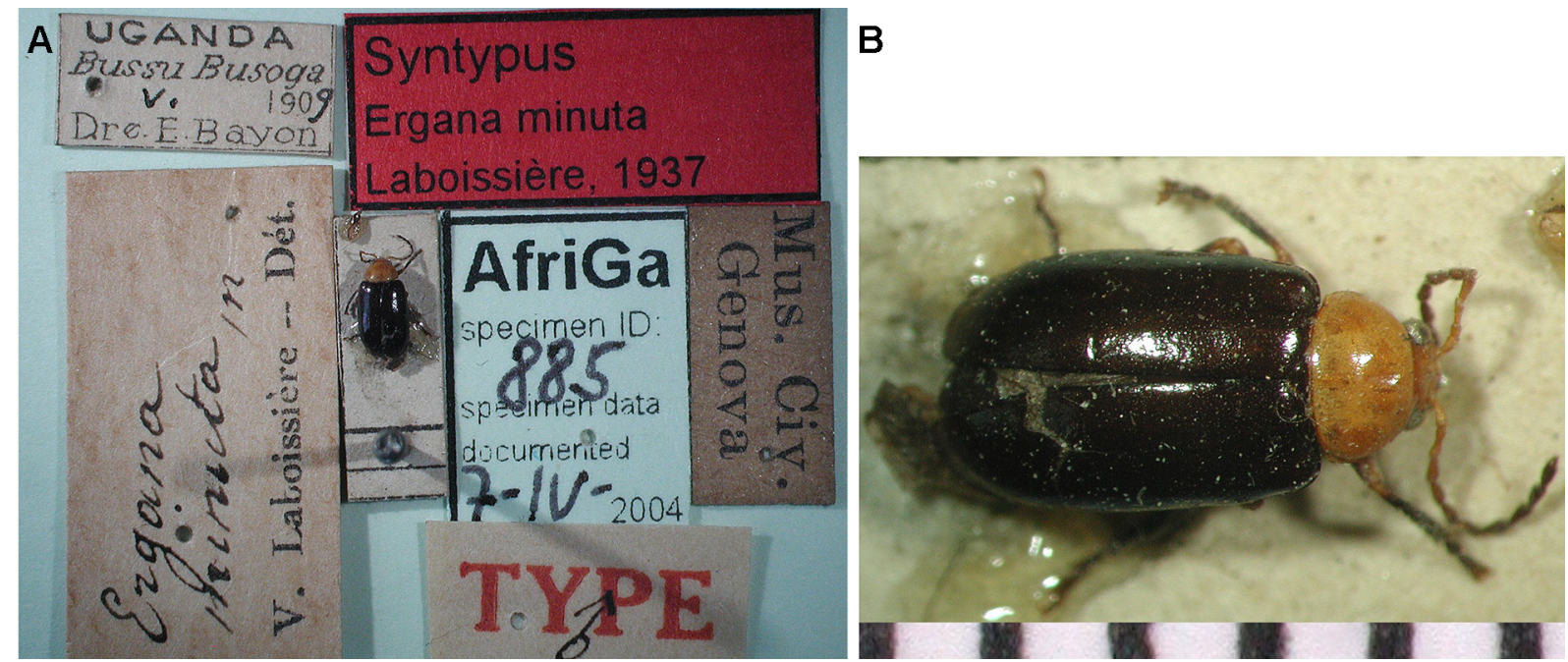

Fig. 14. Lectotype of Oosagitta minuta comb. nov. A. Overview with labels. B. Close-up of specimen. 


\section{Other material examined}

DEMOCRATIC REPUBLIC OF THE CONGO: 2 exx., Parc Nat. de la Upemba, affl. Lusinga (1585 m), 0.733/28.62, Dec. 1947, Miss. G.F. de Witte (IRSNB); 5 exx., Parc Nat. de la Upemba, Lusinga (1760 m), 0.167/26.30, Dec. 1947, Miss. G.F. de Witte (IRSNB); 2 exx., Parc Nat. de la Upemba, Mabwe (r. E. lac Upemba), 585 m, -8.65/26.52, Dec. 1948, Miss. G.F. de Witte (MRAC).

SOUTH AFRICA: 1 ex., Natal, Malvern, C.I.E. Coll. No. 15946, G.E. Bryant det.: Ergana proteus (BMNH); 1 ex., Südafrika: Transvaal, lekgalameetse Nat. Res., -24.08/30.25, Dec. 1995, F. Koch (MNHU).

\section{Redescription}

MEAsurements. $\mathrm{n}=12$, total length $3.10-4.20 \mathrm{~mm}$ (mean $3.75 \mathrm{~mm}$; Fig. 10), maximum height in lateral view $1.30-1.50 \mathrm{~mm}$ (mean $1.40 \mathrm{~mm}$ ).

HEAD. Yellowish to brown, mandibles dark brown. Maximum width of eye to minimum distance between eyes $0.55-0.78$ (mean 0.68). Length of second to third antennomere $0.5-0.75$ (mean 0.64 ), length third to fourth antennomere $0.67-0.89$ (mean 0.78; Fig. 11). Basal antennomeres yellowish, antennae becoming darker towards the apex. Mean antennal length to total body length ratio 0.60 .

Thorax. Pronotum yellowish with very delicate punctation. Pronotal width $1.00-1.50 \mathrm{~mm}$ (mean $1.28 \mathrm{~mm}$ ), length of pronotum $0.65-0.95 \mathrm{~mm}$ (mean $0.81 \mathrm{~mm}$ ), pronotal width to length $1.41-1.77$ (mean 1.57). Elytron dark brown, irregular punctation, coarser than pronotum. Elytral length 2.35$3.25 \mathrm{~mm}$ (mean $2.82 \mathrm{~mm}$ ), maximum width of both elytra combined 1.80-2.60 mm (mean $2.23 \mathrm{~mm}$ ), ratio of maximum width of elytra combined to length of elytron $0.73-0.88$ (mean 0.79). Pro-, meso- and metathorax, abdomen and legs dark brown, coxae and distal/proximal parts of tarsomeres yellowish or light brown. Tibia has all around setae and is gently curved. Length of basimetatarsus to length of metatibia $0.25-0.35$ (mean 0.30).

Male genitalia. The symmetric median lobe tapers and is down-curved in lateral view. The tectum is shorter than median lobe and nearly triangular (Fig. 12A). Tectorial spures are very slender, the basal two thirds covered by the tectum, the apices very fine and dorsally hooked (Fig. 12A, C). Endophallus with broad base fine "arrow-hooks" (Fig. 12A, B). Basal orifice of median lobe ovoid with an incision (Fig. 12A).

\section{Distribution}

Known from southern Uganda, southeastern Congo and from the northern states of South Africa (Fig. 13).

$$
\begin{aligned}
& \text { Oosagitta anningae sp. nov. } \\
& \text { urn:lsid:zoobank.org:act:76E6057D-8AB6-4DA8-BE69-CC7BF76F68BC }
\end{aligned}
$$

Figs 13, 15-18

\section{Differential diagnosis}

Oosagitta anningae sp. nov. is completely yellowish, while $O$. angolensis comb. nov. has a brown head and pronotum and yellowish elytron, $O$. geescheae sp. nov. has a brown pattern on yellowish elytron, $O$. thomasi sp. nov. has brown antennomeres, $O$. melanoptica sp. nov has a dark brown postocular patch and $O$. minuta comb. nov. has dark brown elytron. It is the only species from tropical western Africa and occurs allopatrically with all other species. A definitive identification is possible by examination of the shape of male genitalia (Fig. 17). 


\section{Etymology}

Named after Sabine Kortenhaus' daughter Anning.

\section{Type material}

\section{Holotype}

đ, “Coll. Mus. Tervuren Côte d'Ivoire: Bingerville, Sep. 1963, J. Decelle/AfriGa specimen ID 1898, 26.XI.2012” (MRAC) (Fig. 18).

\section{Paratypes}

GHANA: 3 exx., Takoradi, 4.88/-1.75, Besnard (MRAC).
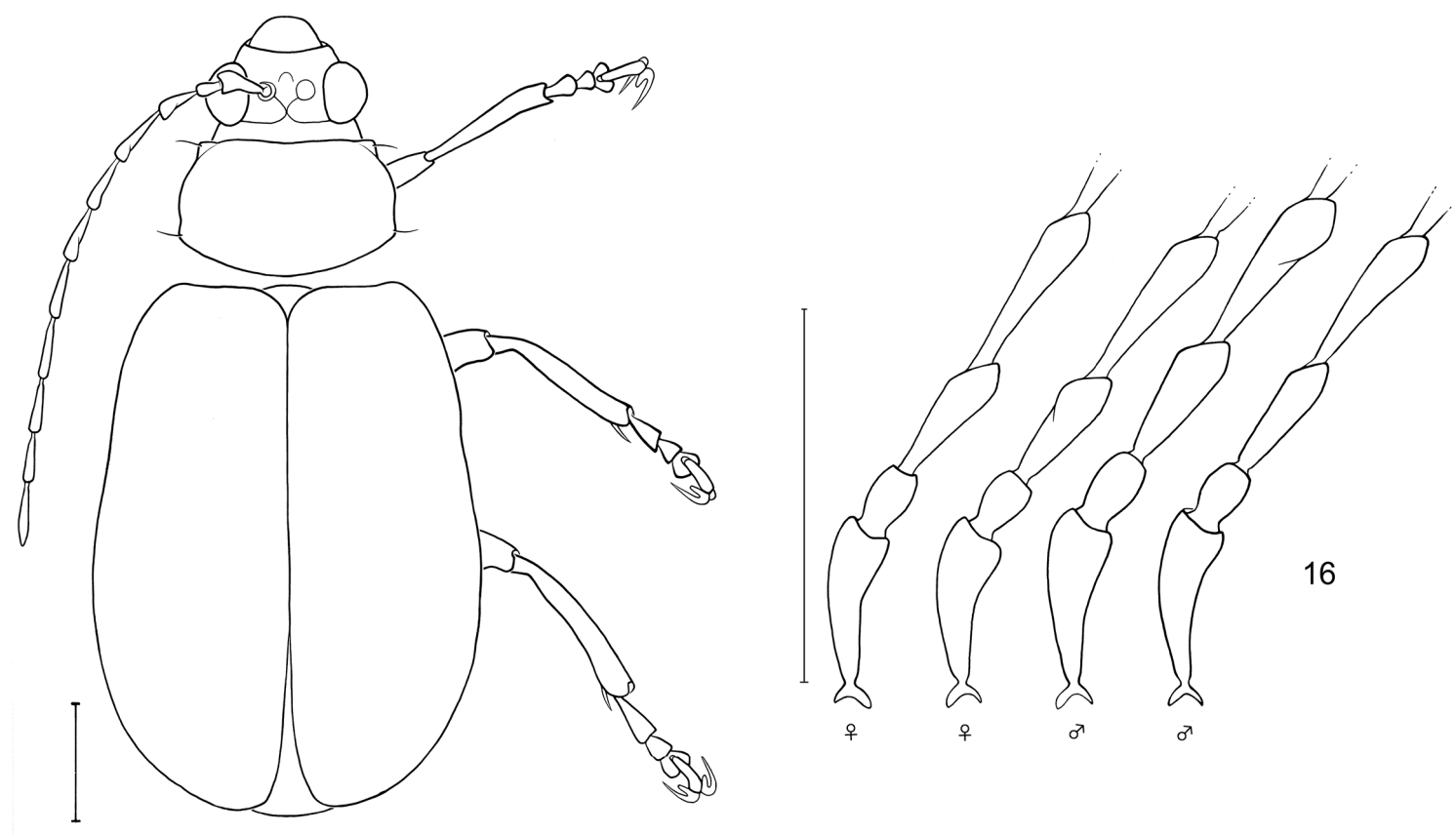

15

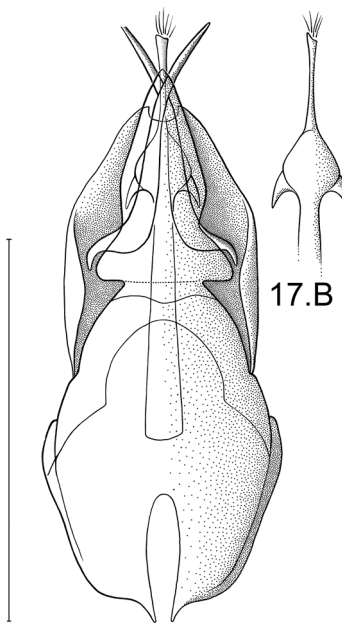

17.A

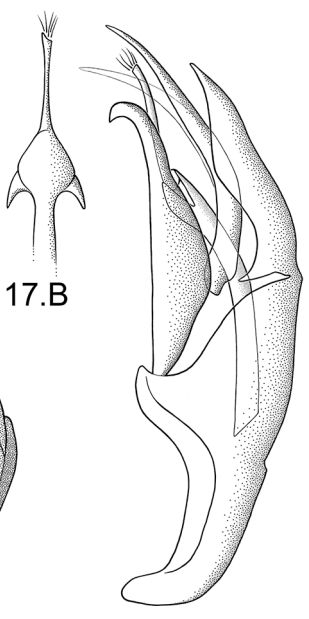

17.C

Figs 15-17. O. anningae sp. nov. 15. Habitus, semi-schematic dorsal view. 16. Basal four antennomeres of $2 \widehat{\partial} \widehat{\gamma}$ and 2 우. 17. Median lobe. A. Dorsal. B. Detail: apex of endophallus. C. Lateral. Scale bars: $1 \mathrm{~mm}$. 
IVORY COAST: 2 exx., Adiopodoumé, 5.34/-4.13, Aug. 1952 (MNHN); 1 ex., Adiopodoumé, Feb. 1957, P. Dessart (MRAC); 1 ex., Zepreghe-Koffikro (Daloa), 6.91/-6.37, Jul. 1961, J. Decelle (MRAC); 2 exx., Bingerville, 5.36/-3.89, Feb. 1963, J. Decelle (MRAC).

TOGO: 1 ex., Misahöhe, 6.95/0.58, May 1894, E. Baumann (MNHU).

\section{Type locality}

IVORY COAST: Bingerville, 5.36/-3.89.

\section{Description}

MeAsuRements. $\mathrm{n}=11$, total length $4.25-5.35 \mathrm{~mm}$ (mean $4.85 \mathrm{~mm}$; Fig. 15); maximum height in lateral view $1.60-2.05 \mathrm{~mm}$ (mean $1.80 \mathrm{~mm})$.

Head. Yellowish, mandibles darker brown. Maximum width of eye to minimum distance between eyes 0.73-0.83 (mean 0.79). Length of second to third antennomere 0.36-0.50 (mean 0.43), length third to fourth antennomere $0.69-0.83$ (mean 0.75; Fig. 16). Antennae yellowish. Mean antennal length to total body length ratio 0.91 .

THorax. Pronotum yellowish with very delicate punctation. Pronotal width 1.50-1.90 mm (mean $1.71 \mathrm{~mm}$ ), length of pronotum $0.90-1.20 \mathrm{~mm}$ (mean $1.05 \mathrm{~mm}$ ), pronotal width to length 1.50-1.73 (mean 1.62). Elytron is yellowish and has irregular punctation, only a bit coarser than pronotum. Elytral length 3.35-4.25 mm (mean $3.91 \mathrm{~mm}$ ), maximum width of both elytra combined 2.50-3.45 $\mathrm{mm}$ (mean $3.04 \mathrm{~mm}$ ), ratio of maximum width of elytra combined to length of elytron $0.73-0.83$ (mean 0.78 ). Pro-, meso- and metathorax, abdomen and legs are yellowish. Tibia is gently curved. Length of basimetatarsus to length of metatibia $0.24-0.32$ (mean 0.29 ).

MaLE Genitalia. Aedeagus very broad, rather erect, only the outermost apex of median lobe and tectum curved ventrally (Fig. 17C). The slightly waisted, broad tectum covers basal two thirds of very long, slightly bent and apically crossed tectorial spures that are much longer than the ventral part of the median lobe (Fig. 17A). Endophallus long, with slender base, two short "arrow-hooks" and very slender and long apical part that is emerging out of the median lobe (Fig. 17A, B). Orifice of median lobe ovoid with a rather deep incision (Fig. 17A).

\section{Distribution}

Western Africa from Ivory Coast towards Togo (Fig. 13).
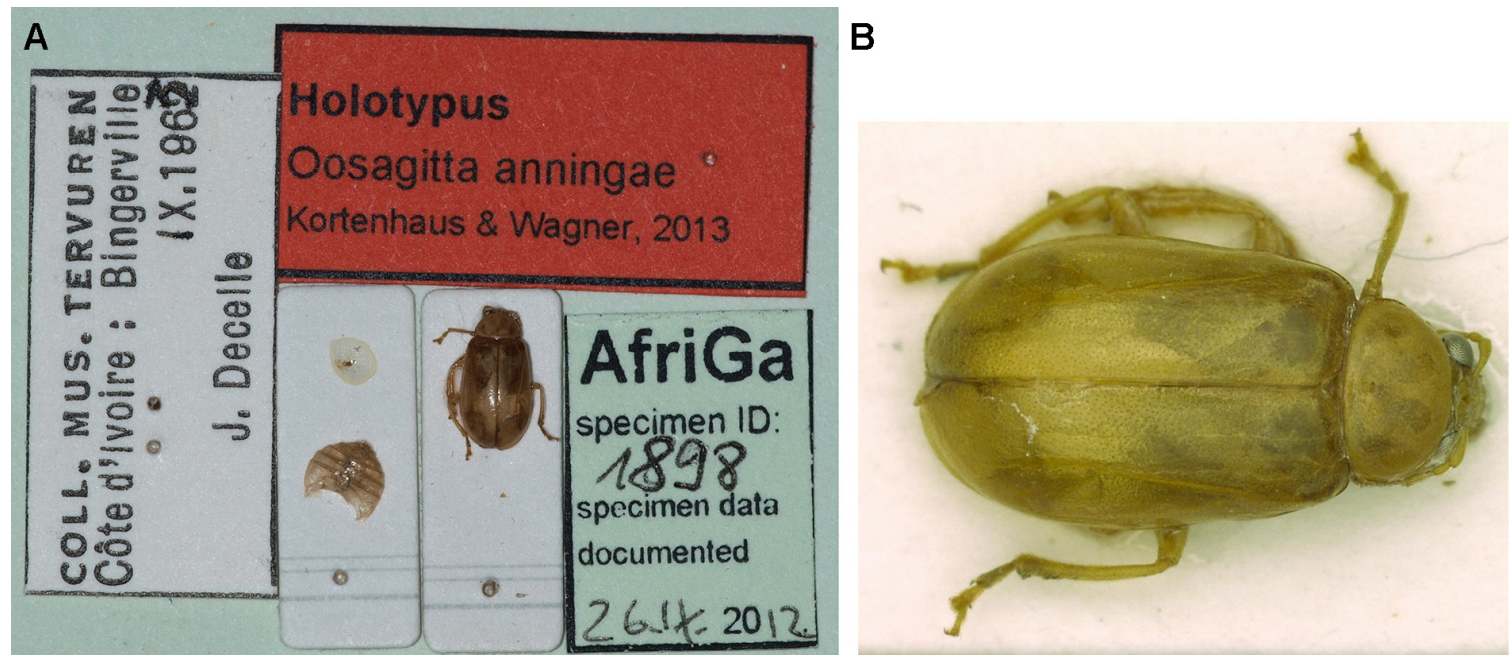

Fig. 18. Holotype of $O$. anningae sp. nov. A. Overview with labels. B. Close-up of specimen. 
Oosagitta geescheae sp. nov.

urn:1sid:zoobank.org:act:C9A28FBA-6047-4F16-96B3-C752A4642E8F

Figs 13, 19-23

\section{Differential diagnosis}

Oosagitta geescheae sp. nov. is the only species of the genus that possesses a brownish elytral base and apex on yellowish elytron. The endophallus with slender, spatula-like tectum and the very long, slender tectorial spures are very characteristic for this species.

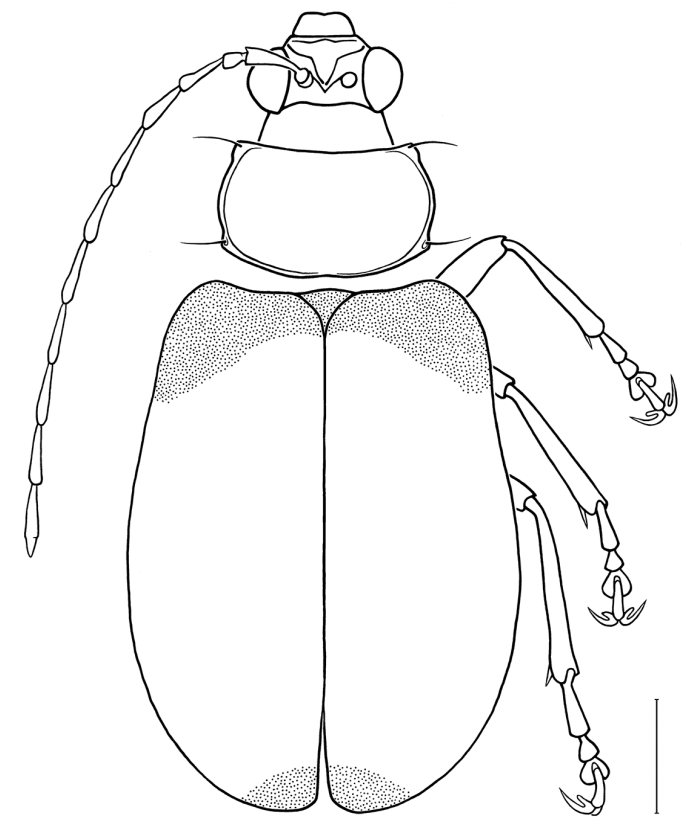

19
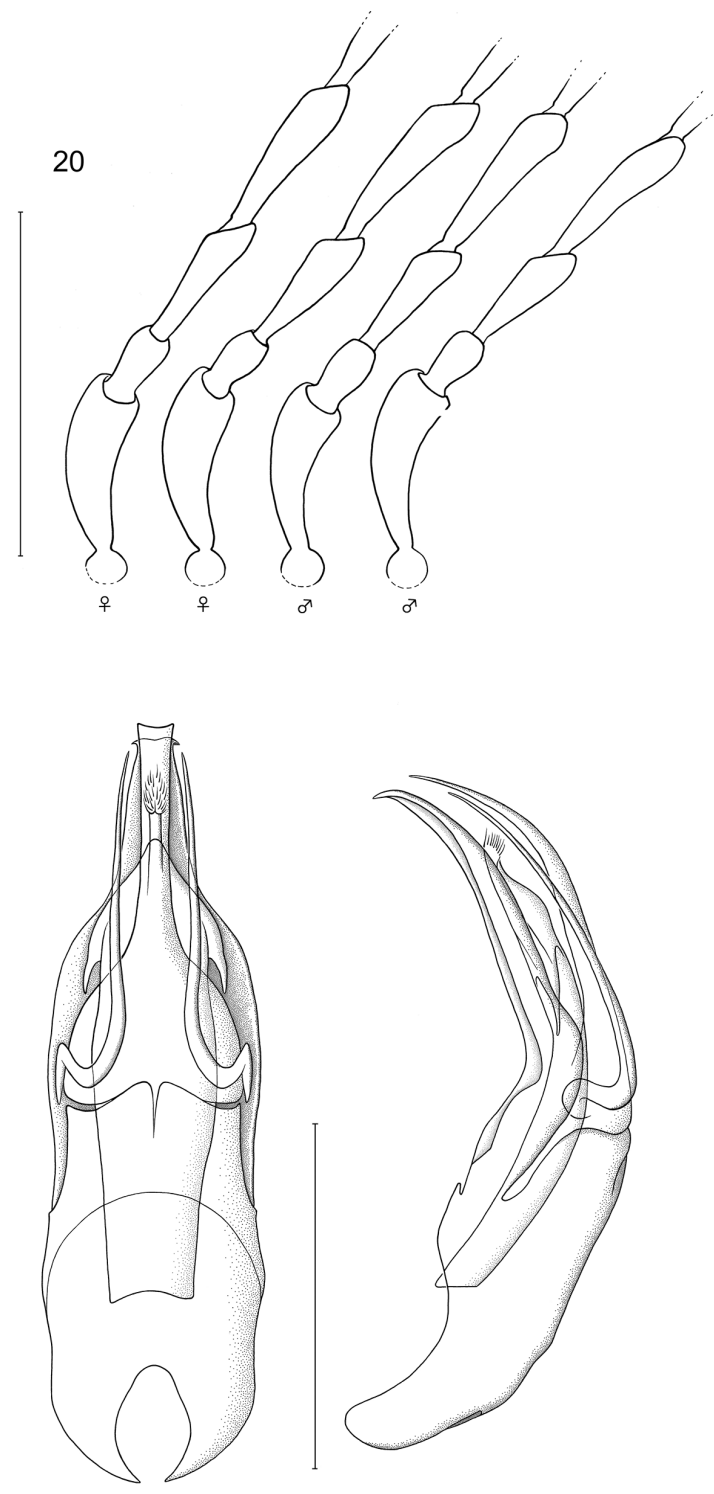

21.A

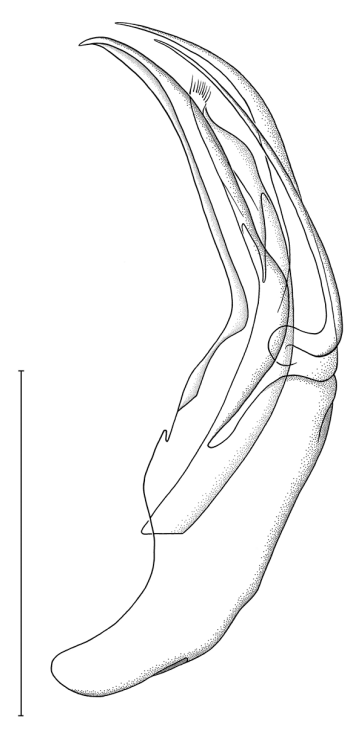

21.B

Figs 19-21. Oosagitta geescheae sp. nov. 19. Habitus, semi-schematic dorsal view. 20. Basal four antennomeres of $2 \hat{\partial}$ and 2 q $q$. 21. Median lobe. A. Dorsal. B. Lateral. Scale bars: $1 \mathrm{~mm}$. 


\section{Etymology}

Named after Sabine Kortenhaus' daughter Geesche.

\section{Type material}

\section{Holotype}

đ, "Musée du Congo Lomami: Kaniama, 1931, R. Massart/AfriGa specimen ID 1897, 26.XI.2012" (MRAC) (Fig. 22).

\section{Paratypes}

CAMEROON: 2 exx., Johann Albrechtshöhe [Mt. Cameroon], 4.15/9.21, ex. Coll. J. Weise, 1 ex. with additional label "Type/Candezea transversicollis Jac. Typ." in Weise's handwriting; this species was not described (MNHU); 1 ex., Kamerun, Barombi, 4.40/9.25, Conrad (HNHM).

DEMOCRATIC REUBLIC OF THE CONGO: 1 ex., Bena-Bendi, Sankuru, -4.28/20.35, Jan. 1895, L. Cloetens (IRSNB); 1 ex., Kassai, 1904, E. Taymans (IRSNB); 1 ex., Elisabethville [Lubumbashi], -11.67/27.47, Nov. 1911, Miss. Agric. (MRAC); 1 ex., Kwamouth, -3.18/16.20, Jun. 1913, Dr. J. Maes (MRAC); 1 ex., Tang. Moero, Niunzu, 1935, H. De Saeger (MRAC); 1 ex., PNA, Secteur Nord, riv. Talya, affl. dr. Lume, 1215 m, Jul. 1956, P. Vanschuytbroeck (IRSNB); 2 exx., PNA, Secteur Nord, riv. Talya, affl. dr. Lume, 1280 m, Jul. 1956, P. Vanschuytbroeck (IRSNB); 1 ex. PNA, Massif Ruwenzori, riv. Talya, affl. Lume, 1870 m, 0.38/29.90, Sep. 1956, P. Vanschuytbroeck (IRSNB); 1 ex., PNA, Secteur Nord, Gundu, affl. rive dr. Semliki, reg. Kylia, 840 m, -1.65/28.87, Jan. 1957, P. Vanschuytbroeck (IRSNB); 1 ex., Tshuapa, Bamanga, -0.28/25.53, 1960, P. Hulstaert (MRAC).

UGANDA: 3 exx., Bwamba, -0.65/29.83, Jun. 1948, Van Someren (1 ex. BMNH, 2 exx. NMK).

\section{Type locality}

DEMOCRATIC REUBLIC OF THE CONGO: Kaniama, -6.13/24.48.
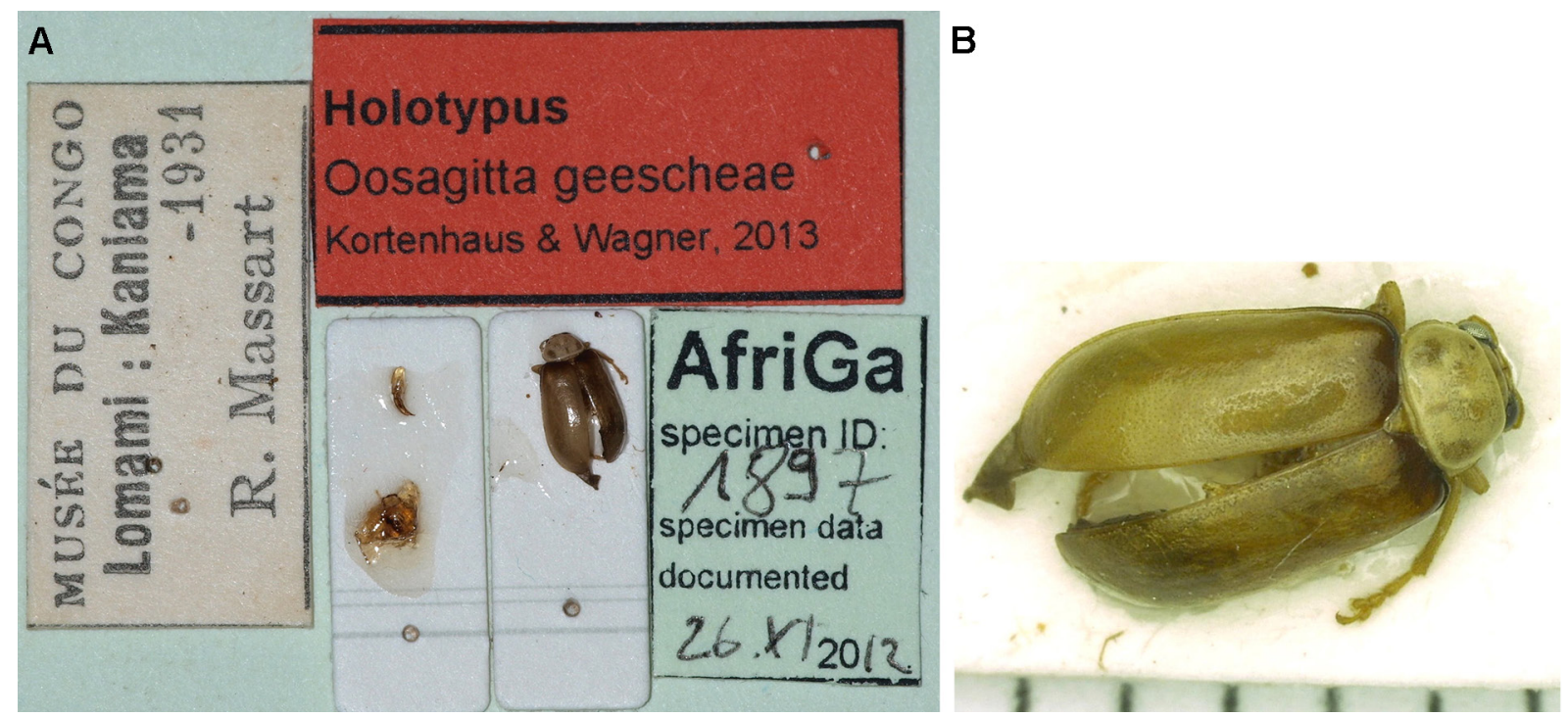

Fig. 22. Holotype of $O$. geescheae sp. nov. A. Overview with labels. B. Close-up of specimen. 


\section{Description}

Measurements. $\mathrm{n}=15$, total length 4.50-5.80 mm (mean $5.33 \mathrm{~mm}$; Fig. 19); maximum height in lateral view $1.50-2.50 \mathrm{~mm}$ (mean $2.01 \mathrm{~mm}$ ).

HEAD. Yellowish, becoming darker towards labrum. Maximum width of eye to minimum distance between eyes $0.69-0.92$ (mean 0.83). Length of second to third antennomere 0.38-0.57 (mean 0.48), length third to fourth antennomere $0.63-0.75$ (mean 0.69 ; Fig. 20). Antennae yellowish, terminal antennomere with darker apex. Mean antennal length to total body length ratio 0.93 .

Thorax. Colour like head, pronotum and disc of elytron. Pronotum yellowish with delicate punctation. Pronotal width $1.50-1.95 \mathrm{~mm}$ (mean $1.77 \mathrm{~mm}$ ), length of pronotum $0.88-1.10 \mathrm{~mm}$ (mean $1.04 \mathrm{~mm}$ ), pronotal width to length 1.62-1.86 (mean 1.71). The yellowish elytron has a brownish base and apex of elytron (Fig. 19) and an irregular coarse punctation. Elytral length 3.73-4.95 mm (mean $4.33 \mathrm{~mm}$ ), maximum width of both elytra combined $2.75-3.50 \mathrm{~mm}$ (mean $3.22 \mathrm{~mm}$ ), ratio of maximum width of elytra combined to length of elytron $0.67-0.81$ (mean 0.75 ). Scutellum integrated in the pattern of elytron (Fig. 19). Pro-, meso- and metathorax, abdomen and legs yellowish. Length of basimetatarsus to length of metatibia $0.29-0.33$ (mean 0.32 ).

Male genitalia. The symmetric conical aedeagus slightly curved ventrally (Fig. 21B), median lobe tapers to two short points, separated by a tiny incision (Fig. 21A). Tectum with very broad base, which narrows to a ventrally bent, spatulate, nearly rectangular structure. Tectorial spures nearly circular bent at base, very long and slender toards the apex (Fig. 21A, B) Endophallus possesses two acute tapering appendices at its apex. Endophallus brush is emerging from this arrow-like endophallus Fig. 21B). Orifice of median lobe ovoid with a rather great incision (Fig. 21A).

\section{Distribution}

Cameroon, Congo Basin and western Uganda (Fig. 13).

Oosagitta thomasi sp. nov. urn:1sid:zoobank.org:act:61E0C9B7-DF5B-42C8-B5F9-479A1FE11E20

Figs 8, 23-26

\section{Differential diagnosis}

With regard to elytral coloration, $O$. thomasi sp. nov. differs from $O$. geescheae sp. nov. (with basal and apical pattern) and $O$. minuta comb. nov. (dark brown elytron). The basal antennomere is yellowish and all following ones are brown, while $O$. angolensis comb. nov. has completely brown antennae and $O$. anningae sp. nov and $O$. melanopicta sp. nov. have yellowish antennae. Only $O$. minuta comb. nov. has a similar antennal coloration, but is significant smaller. Clear differentiation is given by the shape of median lobe: the tectorial spures are nearly as long as tectum (Figs 25A, 25B), while O. angolensis comb. nov. has a longer, more curved tectum (Fig. 7C). Tectum of $O$. geescheae sp. nov. is spatulate (Fig. 21A) and O. melanoptica sp. nov. has longer, more slender and crossed tectorial spures (Fig. 29B). Median lobes of O. minuta comb. nov. (Fig. 12A) and O. anningae sp. nov. (Fig. 17A) are clearly different.

\section{Etymology}

Named after Sabine Kortenhaus' husband Thomas. 


\section{Type material}

\section{Holotype}

đ, “Coll. Mus. Tervuren, Nigeria: Jos, X/XII. 1965, E. Bot Gwong/AfriGa specimen ID 1899, 15.III.2012” (MRAC) (Fig. 26).

\section{Paratypes}

NIGERIA: $1 \hat{\jmath}, 2$ + + , same data as holotype.
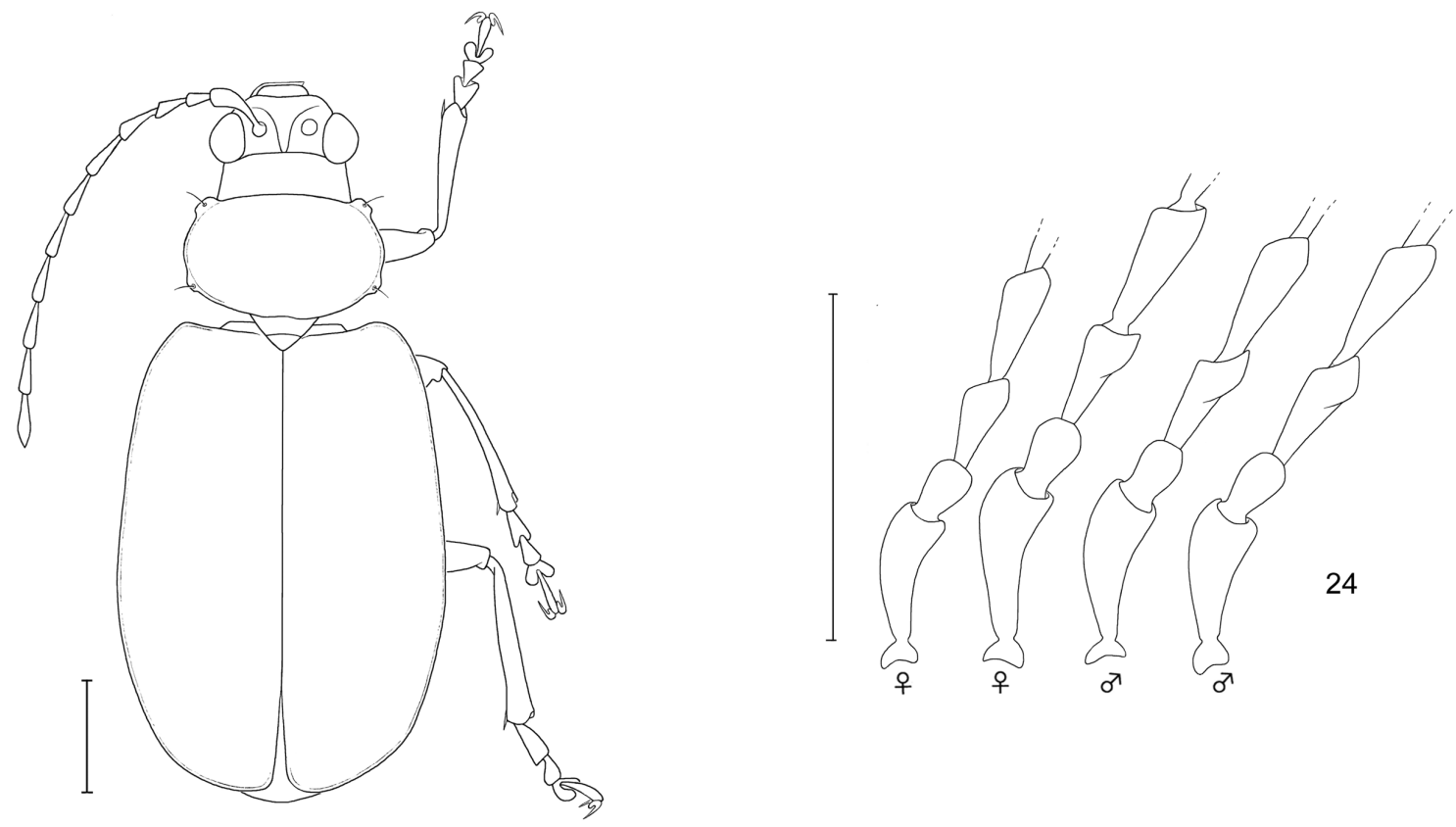

23

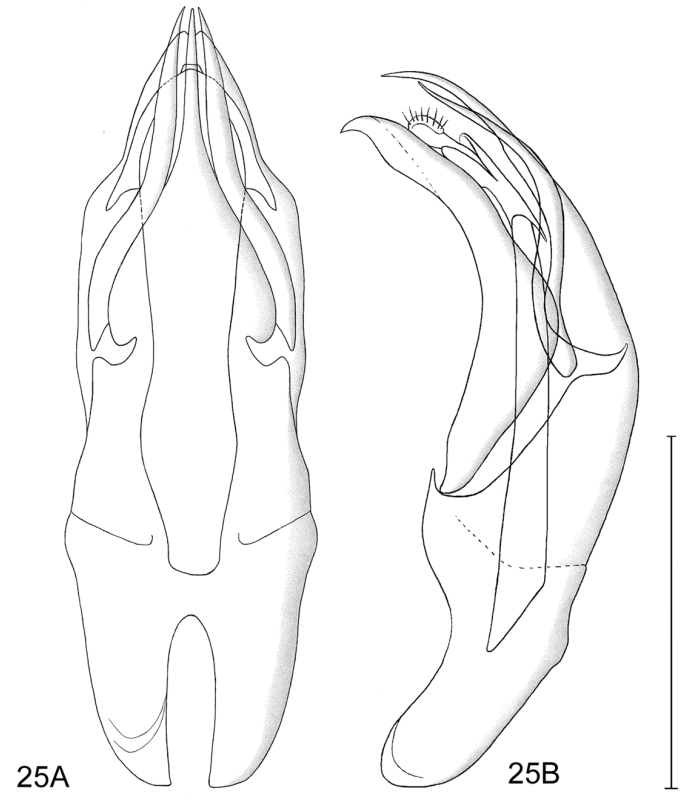

Figs 23-25. Oosagitta thomasi sp. nov. 23. Habitus, semi-schematic dorsal view. 24. Basal four antennomeres of $2 \widehat{\delta}$ and 2 우. 25. Median lobe. A. Dorsal. B. Lateral. Scale bars: $1 \mathrm{~mm}$. 
BURUNDI:1 ðૈ, Urundi: Bururi, -3.95/29.69, R.P. Giraudin, ex coll. Breuning (MRAC).

DEMOCRATIC REPUBLIC OF THE CONGO: 1 ô, I.R.S.A.C., Kivu, Kavimvira [Karimviza], -3.35/29.16 (Uviva), Jan. 1956, G. Marlier (MRAC).

\section{Type locality}

NIGERIA: Jos, 9.92/8.09.

\section{Description}

MeAsuRements. $\mathrm{n}=6$, total length $4.65-5.50 \mathrm{~mm}$ (mean $5.12 \mathrm{~mm}$; Fig. 23); maximum height in lateral view $1.85-2.20 \mathrm{~mm}$ (mean $2.02 \mathrm{~mm})$.

HEAD. Yellowish. Maximum width of eye to minimum distance between eyes $0.61-0.75$ (mean 0.67). Maxillary palps and mandibles brown. Length of second to third antennomere $0.55-0.62$ (mean 0.59), length third to fourth antennomere 0.69-0.79 (mean 0.75; Fig. 24). Basal antennal article yellowish, following antennomeres brown. Antennal length to total body length $0.75-0.82$ (mean 0.78).

Thorax. Yellowish like head, pronotum and disc of elytron. Pronotum with very delicate punctation. Pronotal width $1.50-1.80 \mathrm{~mm}$ (mean $1.65 \mathrm{~mm}$ ), length of pronotum $0.95-1.10 \mathrm{~mm}$ (mean $1.06 \mathrm{~mm}$ ), pronotal width to length 1.50-1.63 (mean 1.56). The yellowish elytron has an irregular coarse punctation. Elytral length $3.90-4.40 \mathrm{~mm}$ (mean $4.13 \mathrm{~mm}$ ), maximum width of both elytra combined $2.60-3.30 \mathrm{~mm}$ (mean $2.97 \mathrm{~mm}$ ), ratio of maximum width of elytra combined to length of elytron 0.66-0.80 (mean 0.72). Pro-, meso- and metathorax, abdomen yellowish. Legs yellowish, only basal part of tibia and tarsi brownish. Length of basimetatarsus to length of metatibia 0.30-0.33 (mean 0.31).

MaLe Genitalia. Median lobe broad, conical in the apical quarter, strongly curved ventrally (Fig. 25A, B), apex with shortly curved tip (Fig. 25B). Tectum short, very broad at base, aoical half very narrow reduces to an elongated, ventrally bent, apical point. It has comparatively short, slender tectorial spures, which are nearly as long as the tectum (Figs 25B). Endophallus brush is emerging from a very broad, arrow-like structure (Fig. 25). Orifice of median lobe ovoid with a great incision (Fig. 25A).

\section{Distribution}

Nigeria, Congo Basin, Burundi (Fig. 8).
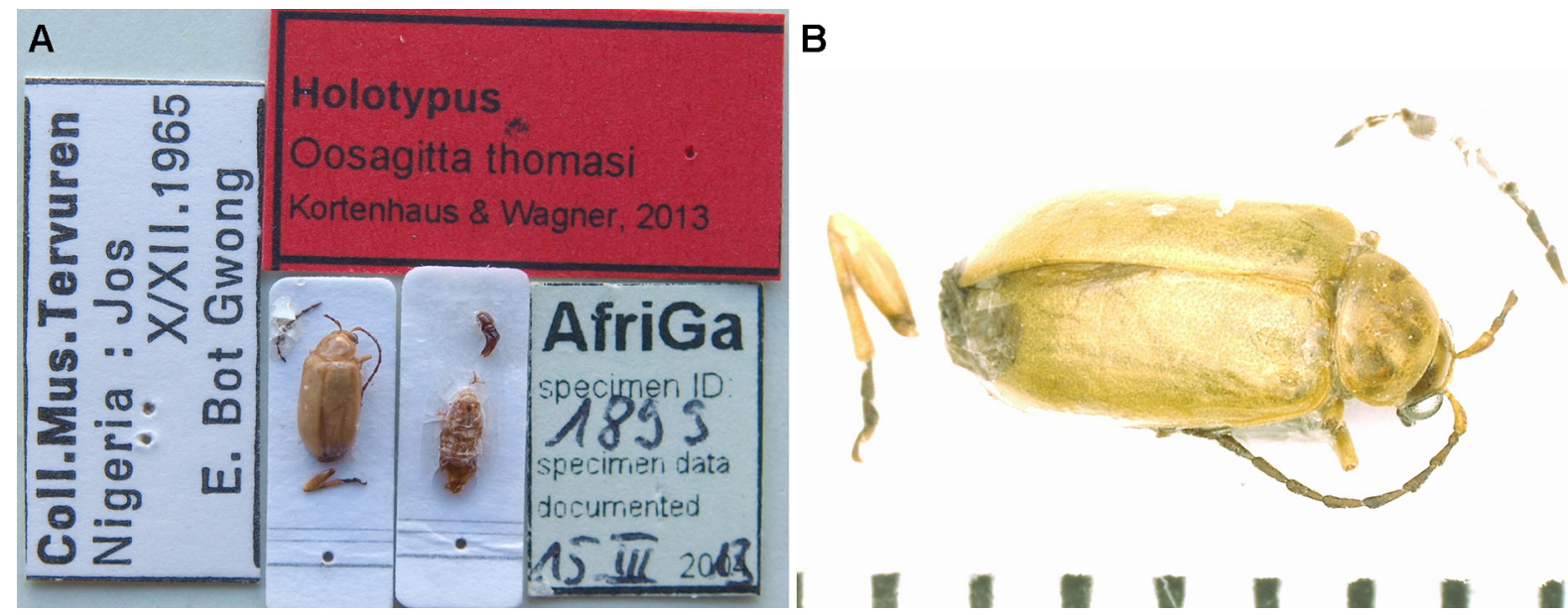

Fig. 26. Holotype of $O$. thomasi sp. nov. A. Overview with labels. B. Close-up of specimen. 
Oosagitta melanopicta sp. nov. urn:Isid:zoobank.org:act:4E493FBA-DE58-4EE4-9DE4-79D63C0FD211

Figs 8, 27-30

\section{Differential diagnosis}

Oosagitta melanoptica sp. nov. has a peculiar character in the significant black patch behind the eye. Further differentiation is possible by the characteristic broad shape of the median lobe.

\section{Etymology}

Named after the significant dark brown postocular patch.
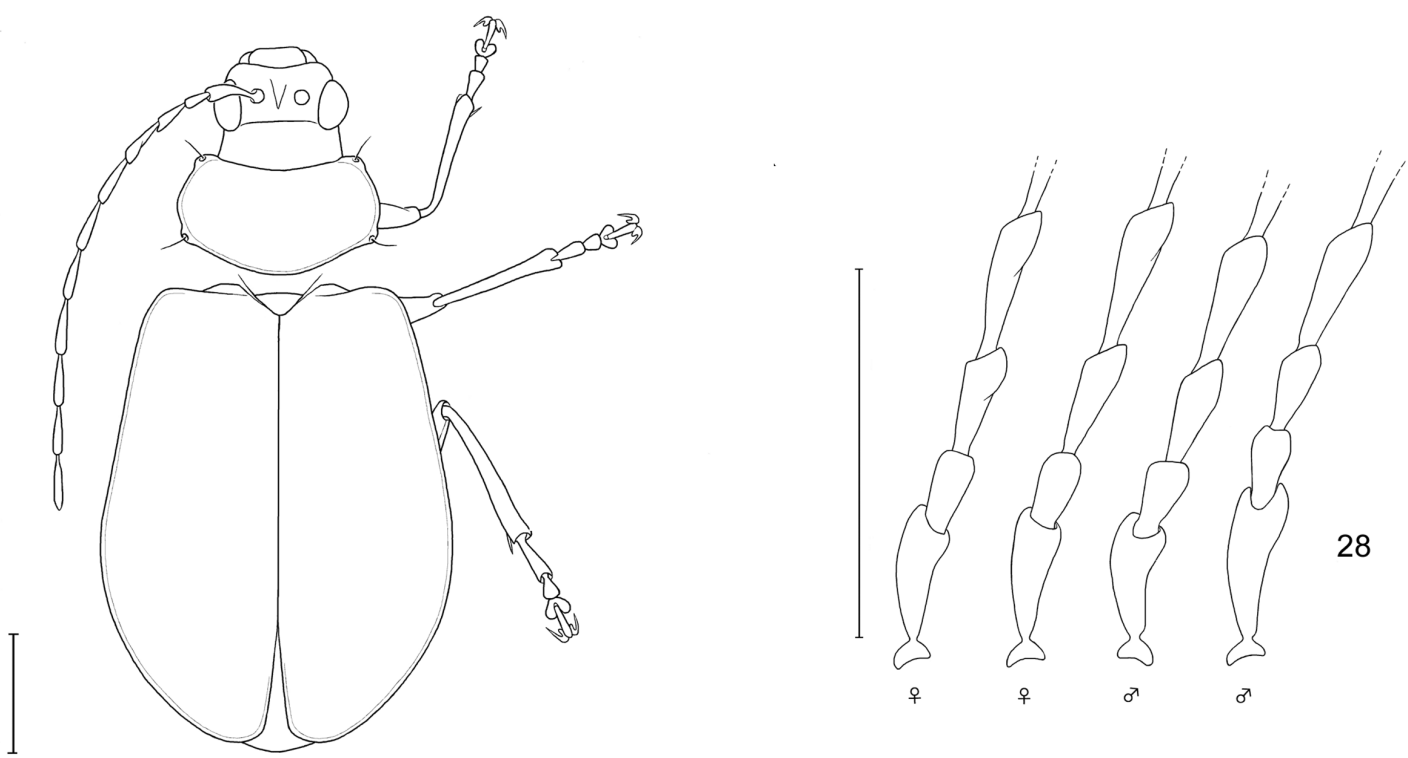

27

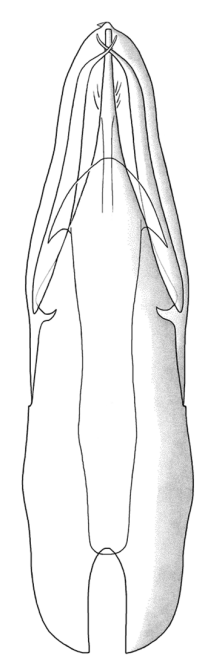

29.A

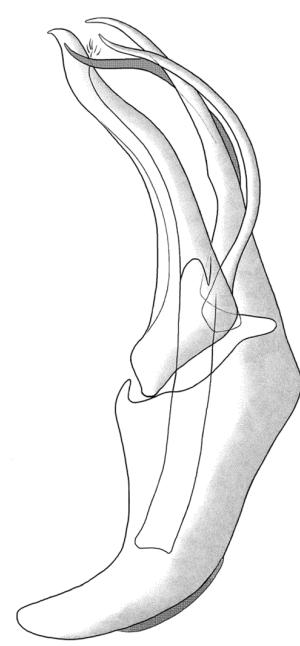

29.B

Figs 27-29. Oosagitta melanopicta sp. nov. 27. Habitus, semi-schematic dorsal view. 28. Basal four antennomeres of $2 \lesssim \Uparrow$ and 2 우. 29. Median lobe. A. Dorsal. B. Lateral. Scale bars: $1 \mathrm{~mm}$. 


\section{Type material}

\section{Holotype}

đૈ, "Coll. Mus. Congo, Stanleyville: Yangambi, km 7, 29.V.1956, R. Damoiseau, C.00.53/Récolté sur Canvalaria curiformis/AfriGa specimen ID 1900, 15.III.2013” (MRAC).

\section{Paratypes}

DEMOCRATIC REPUBLIC OF THE CONGO: $1 \hat{\jmath}, 2$ qq+, same data as holotype; $1 \hat{\jmath}$, Mayidi, -5.19/15.15, 1942, P. Van Eyen (MRAC).

\section{Type locality}

DEMOCRATIC REPUBLIC OF THE CONGO: Stanleyville [Kisangani], Yangambi, 0.81/24.43.

\section{Description}

MeAsurements. $n=5$, total length 4.20 $-4.70 \mathrm{~mm}$ (mean $4.42 \mathrm{~mm}$; Fig. 27); maximum height in lateral view $1.80-2.20 \mathrm{~mm}$ (mean $1.95 \mathrm{~mm}$ ).

HEAD. Yellowish, dark brown postocular patch, labrum brown. Maximum width of eye to minimum distance between eyes $0.63-0.75$ (mean 0.71 ). Length of second to third antennomere $0.58-0.67$ (mean 0.61 ), length third to fourth antennomere $0.63-0.77$ (mean 0.70; Fig. 28). Antennae yellowish. Antennal length to total body length $0.87-0.98$ (mean 0.91 ).

Thorax. Yellowish. Pronotum yellowish nearly without punctation. Pronotal width $1.50-1.75 \mathrm{~mm}$ (mean $1.61 \mathrm{~mm}$ ), length of pronotum $0.85-1.00 \mathrm{~mm}$ (mean $0.92 \mathrm{~mm}$ ), pronotal width to length $1.65-1.94$ (mean 1.76). The elytron is yellowish and has delicate brown margins and an irregular coarse punctation. Elytral length 3.05-3.75 mm (mean $3.35 \mathrm{~mm}$ ), maximum width of both elytra combined $2.60-3.15 \mathrm{~mm}$ (mean $2.94 \mathrm{~mm}$ ), ratio of maximum width of elytra combined to length of elytron 0.81-0.97 (mean 0.88). Metathorax more yellow than pro- and mesothorax and abdomen. Legs paler yellowish. Length of basimetatarsus to length of metatibia $0.29-0.33$ (mean 0.31 ).

MaLE Genitalia. The symmetric conical aedeagus slightly curved ventrally, median lobe tapers to a short point (Fig. 29A, B). Tectum with very broad base, which narrows to a ventrally bent, flattened structure.
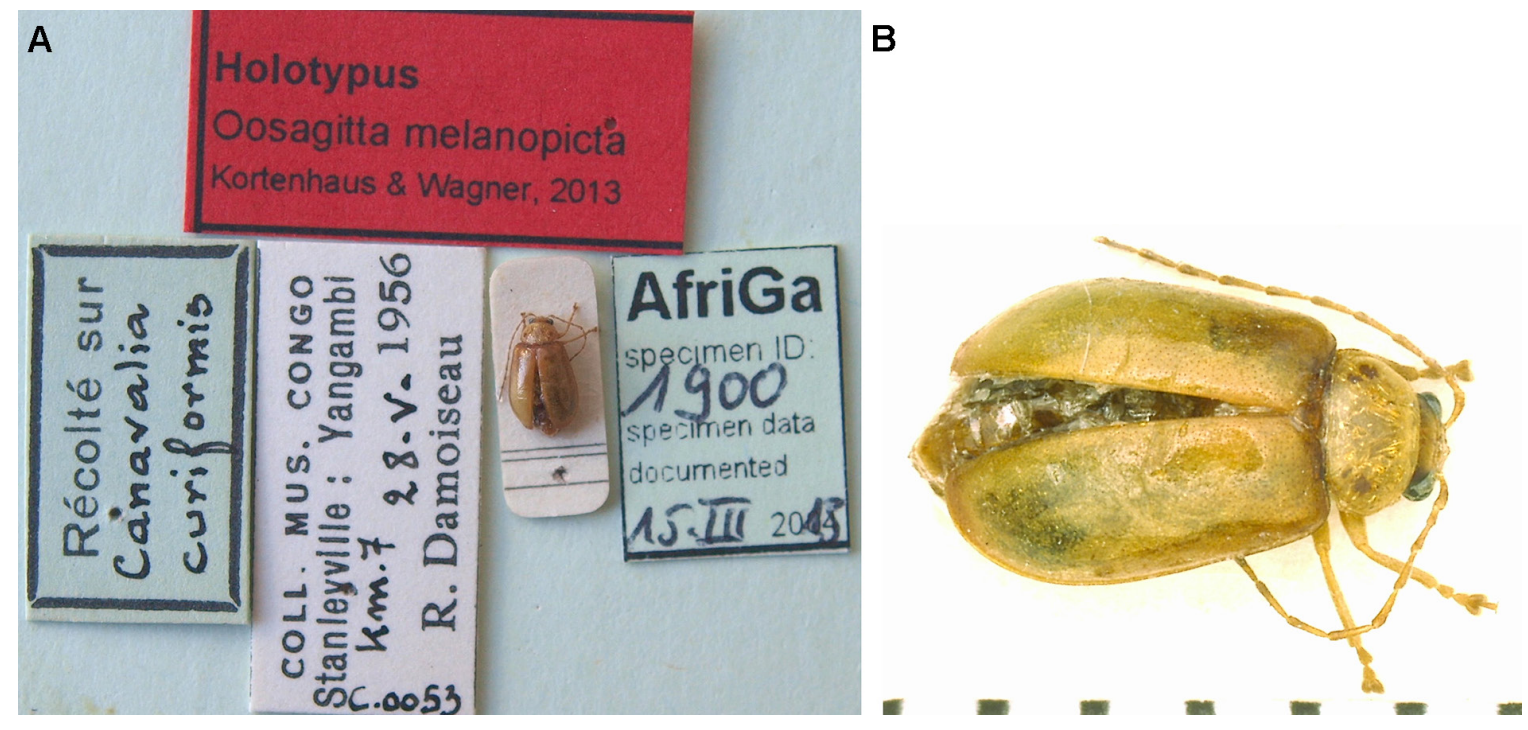

Fig. 30. Holotype of O. melanopicta sp. nov. A. Overview with labels. B. Close-up of specimen. 
Very long, slender and strongly curved tectorial spures intersect themselves nearly at the apex. Apically these structures are curved dorsally (Fig. 29A, B). Endophallus brush is emerging from the arrow-like endophallus (Fig. 29A). Orifice of median lobe ovoid with a rather great incision (Fig. 29A).

\section{Distribution}

Only known from two sites along the Congo River (Fig. 8).

\section{Identification key}

1. Elytra dark brown, total body length $<4.20 \mathrm{~mm}$, tectum shorter than median lobe with hooked tectorial spurs (Fig. 12A, C); Uganda, SE Congo and northern states of South Africa (Fig. 13)

Oosagitta minuta (Laboissière, 1937) comb. nov.

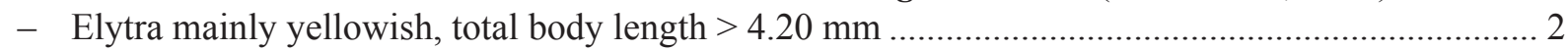

2. Elytron yellowish with a light brown base and apex (Fig. 19), median lobe with tectum narrows to a rectangular, spatulate structure (Fig. 21A); Cameroon, Congo Basin towards western Uganda (Fig. 13) .

Oosagitta geescheae sp. nov.

- Elytron unicolor pale yellowish to yellowish-brown... 3

3. Pronotum and head dark brown, contrasting to the yellowish to yellowish-brown elytra, median lobe with incised apex, ventrally bent, elongated, slender tectum (Fig. 7A); widely distributed in central, east and southern Africa (Fig. 8). Oosagitta angolensis (Laboissière, 1939) comb. nov.

- Head, pronotum and elytra unicolorous yellowish 4

4. Scapus yellowish, antennomere $2-11$ brown, median lobe broad, tectum very broad at base stringly narrowed in the apical half (Fig. 25A, B); known from Nigeria, Congo Basin and Burundi (Fig. 8)

Oosagitta thomasi sp. nov.

- Antennae yellowish throughout..... 5

5. Head yellow with significant postocular dark brown to black spot, ventral part of median lobe about the same length as tectum and tectorial spures (Fig. 29); only knowm from to sites along the Congo River (Fig. 8) Oosagitta melanopicta sp. nov.

- Head yellow throughout, ventral part of median lobe much shorter than the tectm and the apically crossed tectorial spures (Fig. 17); restricted to western Africa from the Ivory Coast to Togo (Fig. 13) .

Oosagitta anningae sp. nov.

\section{Discussion}

During our revision of Ootheca, a group of galerucines endemic to tropical Africa, it became quickly clear that according to the generotype Ootheca mutabilis Sahlberg, 1823, only a "core" group will be remain in that genus. There was obviously no clear generic concept of Ootheca in the nineteenth century, as for many other insect genera, and several leaf beetle species, having a "compact" body shape with broad pronotum, strongly bulged dorsum and short antennae and legs are described in combination with Ootheca. Weise gave a first revision of Ootheca, in which he critically revised the characters of O. mutabilis, that he attributed to Chapuis, 1879, and described three new species from German East Africa (Tanzania). He corrected some misinterpretations, e.g. concerning the prothoracic coxal cavities that Chapuis (1879) described as "ouvertes", but he found as completely closed, what now could be confirmed. Weise also referred to the problems the generic delimitation of Ootheca cause and to the complexity to distinguish the species, but found good evidence for species identification in the male genitalia. This underlines the high quality of his work, since more than one hundred years ago, dissection of genitalia was an unusual method to delimitate insect species. In our recent revision, the male genital 
characters are most crucial for the identification of single species, and also for the delimitation of Ootheca as compared to other galerucine groups taking phylogenetic principles into account. Several characters of the median lobe and endophallic armature can be interpreted as apomorphic characters. After the recent description of Oothecoides and Ootibia, we herein split the third group from Ootheca, where in total six species are characterized by a distinct endophallic pattern that does not, to our knowledge, occur in any other group of Afrotropical galerucines. There are some more species originally described in Ootheca, Ergana, and some further described in Exosoma that are most likely closely related to the genera named above, but not yet revised. Some work is left for the future.

\section{Acknowledgements}

We thank all curators and other colleagues who made material available to us: M. Barclay \& S. Shute $(\mathrm{BMNH})$; D. Drugmand \& P. Limbourg (IRSNB); O. Merkl (HNHM): R. Poggi (MCGD); N. Berti † $(\mathrm{MNHN}) ;$ J. Frisch \& J. Willers (MNHU); M. De Meyer (MRAC); W. Kinuthia \& Ch. Lange (NMK); K. Schütte (ZMUH); D. Ahrens \& K. Ulmen (ZFMK).

\section{References}

Chapuis F. 1879. Phytophages Abyssiniens du Musée Civique d'Histoire naturelle de Gênes. Annali del Museo Civico di Storia Naturale di Genova 15: 15-31.

Kortenhaus S. \& Wagner Th. 2010. Revision of Ootheca Chevrolat, 1837 from tropical Africa Redescriptions, descriptions of new species and identification key (Coleoptera: Chrysomelidae: Galerucinae). Zootaxa 2659: 1-52.

Kortenhaus S. \& Wagner Th. 2011. Oothecoides gen. nov. from tropical Africa, with redescriptions and description of six species (Coleoptera: Chrysomelidae: Galerucinae). Entomologische Zeitschrift 121: 259-269.

Kortenhaus S. \& Wagner Th. 2012. Description of Ootibia gen. n. from tropical Africa with revision of two described species and description of three new species (Coleoptera: Chrysomelidae: Galerucinae). African Entomology 20 (2): 350-370. http://dx.doi.org/10.4001/003.020.0210

Laboissière V. 1937. Galerucinae Africains de la Collection du Musée Civique de Genes. Annales de l'Association des Naturalistes de Levallois-Perret 22: 139-184.

Laboissière V. 1939. Galerucinae (Coleoptera Chrysomelidae) recueillis dans l'Angola par le Dr. Monard. Aquivos do Museu Bocage 10: 87-168.

Manuscript received: 18 March 2013

Manuscript accepted: 5 August 2013

Published on: 11 October 2013

Topic editor: Koen Martens

Desk editor: Charlotte Thionois

Printed versions of all papers are also deposited in the libraries of the institutes that are members of the EJT consortium: Muséum National d'Histoire Naturelle, Paris, France; National Botanic Garden of Belgium, Meise, Belgium; Royal Museum for Central Africa, Tervuren, Belgium; Natural History Museum, London, United Kingdom; Royal Belgian Institute of Natural Sciences, Brussels, Belgium; Natural History Museum of Denmark, Copenhagen, Denmark. 